\title{
Salt Stress Relief and Growth-Promoting Effect of Sweet Pepper Plants (Capsicum annuum L.) by Glutathione, Selenium, and Humic Acid Application
}

\author{
Hassan A. Elkhatib ${ }^{1}$, S.M. Gabr ${ }^{1}$ and A.A. Elazomy ${ }^{2}$
}

\begin{abstract}
Three pot experiments were carried out at a private farm in Abu Homos, El-Beheira Governorate during 2018 and 2019 and 2020 growing seasons to examine the role of Glutathione, Selenium, and Humic Acid solely in the first two seasons and in combinations in the third season in elevation the impact of salinity on vegetative growth (leaves fresh weight, leaves dry weight and leaf area), chemical composition (chlorophyll, N, P, Ca, K, Na, Proline contents, $\mathrm{K} / \mathrm{Na}$ ratio) and yield of sweet pepper cultivar "Madrid". The results illustrated that the growth parameters, chemical composition and yield of sweet pepper decreased by increasing salinity level. The results of the mitigation treatments of Glutathione, Selenium, and Humic acid, showed that the application of either Selenium alone in the first two seasons or combined with Glutathione in the third season showed significant effects for increasing plant growth, nutrient contents and yield under the highest salinity level.
\end{abstract}

Key words: Salt stress, Sweet pepper, Glutathione, Selenium, and Humic acid.

\section{INTRODUCTION}

Pepper (Capsicum annuum L.) is one of the most important consumed vegetables in the world and the nutrition analysis showed that Pepper is an excellent source of many essential nutrients for humans, especially vitamin $\mathrm{C}$, phenolic compounds, flavonoids, tocopherols (vitamin E), carotenoids (pro-vitamin A). Additionally, some pepper cultivars contain significant quantities of Capsaicinoids, a group of pungent phenolic derived compounds with strong physiological and pharmacological properties. Thus, the growing global demand for pepper fruits implies several strategies to increase crop production and fruit quality or promote the investigation to improve the plant resistance to environmental stresses (Jimenez-Garcia et al.,2014). Pepper is one of the most important popular and favorite vegetable crops cultivated in Egypt for local consumption and exportation. The yearly global production of pepper is around 36.771 million tons, harvested from an area that reached about 1.99 million hectares (ha), while in Egypt, the total cultivated area of pepper reached in 2018 statistics about 42132 hectares, with a total production of about 713752 tons (FAO, STAT. 2018). Pepper is moderately sensitive to salinity
(Lee, 2006), therefore, the major factor impacting pepper production in Egypt seems to be high salinity level in soil and irrigation.

Salinity stress is one of the most environmental stresses, which causes major reductions in cultivated area and crop productivity (Shahbaz and Ashraf, 2013) as much as $50 \%$. Worldwide, more than 45 million ha of irrigated land which accounts for $20 \%$ of total land have been damaged by salt, and 1.5 million ha were taken out of production each year due to high salinity levels in the soil (Munns and Tester, 2008). On the other hand, the salinized areas are expected to increase at a rate of $10 \%$ annually for various reasons, including low precipitation, high surface evaporation, weathering of native rocks, irrigation with saline water, and poor cultural practices (Munns and Tester 2008). Hence, the water shortage has emerged as a serious challenge to sustainable develop agriculture. Arid and semi-arid regions are forced to use low-quality waters (brackish, reclaimed, drainage, and wastewater) in irrigation in their long-term development plants (Cartzoulakis et.al., 2000). Salt stress affects plant physiology, both at the whole plant as well as at cellular levels, through osmotic and ionic stress. Osmotic stress causes various physiological changes, such as interruption of membranes, nutrient imbalance, impairs the ability to detoxify reactive oxygen species (ROS), differences in the antioxidant enzymes and decreased photosynthetic activity, and decrease in stomatal aperture, inhibition of water uptake, cell expansion, and lateral bud development (Rahnama et al. 2010).

Salinity stress is also considered as ionic stress through an accumulation of $\mathrm{Na}+$ ions in tissues of plants exposed to soils with high $\mathrm{NaCl}$ concentrations. The entry of $\mathrm{Na}+$ into the cells causes severe ion imbalance and excess uptake might cause significant physiological disorder. High $\mathrm{Na}+$ concentration inhibits the uptake of $\mathrm{K}+$ ions which is an essential element for growth and development that results in lower productivity and may even lead to increased leaf mortality, chlorosis, necrosis, and decreased activity of cellular metabolism including photosynthesis (Zhang and Shi 2013). In recent decades, Various strategies have been used to maximize plant growth and productivity under salinity stress, but it was found the most effective technique to enhance the

DOI: 10.21608/asejaiqjsae.2021.183461

${ }^{1}$ Department of Horticulture, Faculty of Agriculture Damanhour University.

${ }^{2}$ The private sector for vegetable crop production.

Received March 21, 2021, Accepted, July 07, 2021 
plants' growth, yield, as well as stress tolerance under plant protectant compound such as plant hormone antioxidants, signaling molecules, polyamines and trace elements have been found effective in mitigating the salt- induced damage in plants (Hasanuzzaman et al., 2012 and 2013). These protectants showed the capacity to enhance the plants' growth, yield as well as stress tolerance under salinity stress.

Glutathione (GSH) is identified as tripeptide $\gamma$ Lglutamyl-Lcysteinyl- glycine and plays an important role in responding to environmental stresses (Khattab 2007). Also, Glutathione is critical for biotic and abiotic stress management. It is a pivotal constituent of the Glutathione- Ascorbate cycle, a system that decreases toxic hydrogen peroxide that make it an ideal antioxidant that protects cells from free radicals and peroxides (Ghoname et al. 2010). Glutathione is a strong antioxidant that enhancing the endogenous antioxidant levels in plants which resulted in better protection against oxidative stress and helps plants against reactive oxygen species (ROS) (Foyer and Noctor 2005). Furthermore, Glutathione alleviates salt stress by reducing oxidative stress and regulating the number of cell vital functions such as synthesis and repair of DNA and synthesis of proteins (Chen et al. 2012), activation and regulation of enzymes in plants (Nahar et al. 2015); maintains the integrity of cell structures and the proper functions of different metabolic pathways (Chen et al. 2012).

Selenium is an essential micronutrient for animals and humans and appears to be a beneficial element for many plants (Feng et al., 2013). Selenium has an important role in reducing the effects of environmental stress through its effect on the activation of antioxidative defense systems in plant cells (Kaur et al., 2014; Sieprawska et al., 2015). Selenium has a positive influence on changes in the activity and permeability of the cellular membrane (Filek et al. 2008), and acts as a cofactor of the enzyme glutathione peroxidase that catalyzes the reduction of peroxides (Cartes et al. 2005). It has the ability to delay senescence and promotes the growth of aging seedlings (Xue et al. 2001; Pennanen et al. 2002). In addition, Kong et al., (2005) demonstrated that $\mathrm{Se}$ application improved photosynthesis and enhanced salt tolerance in sorrel seedlings. Furthermore, Se application significantly Enhances growth by improving the water balance and cell membrane integrity; increases photosynthetic pigments in tomato seedlings (Diao et al., 2014).

Humic acid (HA) has been proposed as target tool to improve crop production and alleviate the harmful effect of salinity. Clapp et al. (2002) Studied the effects of humic acid on plants and consistently showed stimulation of plant growth by increasing root length and development of secondary roots. Some researchers attributed the stimulative effects of Humic acid to the higher uptake of nutrients. Others, however, suggested that humic acid promotes plant growth through increased cell membrane permeability and exhibited hormone-like activity (Calvo et al., 2014). The enhancing effect of Humic acid on alleviation salinity may be through :stimulates plant growth by accelerating cell division, increasing the rate of development in root systems especially lengthwise (Tan and Nopamornbod, 2005), Increases the permeability of plant membranes and promoting the uptake of nutrients $\mathrm{N}, \mathrm{P}, \mathrm{K}, \mathrm{Ca}$ and $\mathrm{Mg}$ (Mackowiak, et al.,2001), Stimulates growth and proliferation of desirable soil microorganisms as well as algae and yeast and finally increasing the yield of dry matter (Neri et al., 2002). Humic acids also permanently tie up the sodium ion, this helps plants to tolerate the higher sodium concentrations, avoiding toxicity and osmotic related problems. There are indications that the application of humic acid can reduce the negative effects of salinity and improve plant growth parameters as well as enhance mineral uptake in several plant species, including pepper (Canellas et al., 2015; Nardi et al., 2009 and Gemin et al., 2019).

The aims of this study were to evaluate the adverse effects of salinity on the growth of sweet pepper plant and enhancing salt tolerance and eventually improving the productivity of sweet pepper plant under salinity stress by Glutathione, Selenium, and Humic acid application".

\section{MATERIAL AND METHODS}

Three pot experiments were carried out at Raghib farm in Abu Homos, El-Beheira Governorate during 2018, 2019 and 2020 growing seasons to examine the role of Glutathione, Selenium, and Humic acid solely in the first two seasons and in combinations in the third season in elevation the impact of salinity on the vegetative growth, the chemical composition, and yield of sweet pepper cultivar "Madrid"

Soil samples were analyzed for both physical and chemical properties in the laboratory of the Soil Science Department, at Soil, Water and Environment Research Institute-Damanhour, El-Beheira Governorate, Egypt. Soil samples were selected and air dried, ground, sieved through a $2 \mathrm{~mm}$ sieve, and then subjected to determine some soil physical and chemical properties according to Page et al. (1982). Properties of the used soil are shown in Table (1). 
Table 1. Some chemical and physical characteristics of the soil used in the experiments

\begin{tabular}{|c|c|c|c|c|c|c|c|c|c|c|c|c|c|}
\hline \multicolumn{4}{|c|}{ particle size } & \multicolumn{10}{|c|}{ chemical properties } \\
\hline \multirow{2}{*}{$\begin{array}{c}\text { Sand } \\
\%\end{array}$} & \multirow{2}{*}{$\begin{array}{c}\text { Silt } \\
\% \\
\end{array}$} & \multirow{2}{*}{$\begin{array}{c}\text { Clay } \\
\%\end{array}$} & \multirow{2}{*}{$\begin{array}{c}\text { Texture } \\
\text { Class }\end{array}$} & \multirow{2}{*}{$\begin{array}{c}\text { EC } \\
\text { dsm }^{-1}\end{array}$} & \multirow[t]{2}{*}{ pH } & \multicolumn{2}{|c|}{ Soluble cation } & \multirow{2}{*}{$\frac{\mathbf{m g L}^{-1}}{\mathbf{K}^{+}}$} & \multicolumn{3}{|c|}{ Soluble anion $\mathrm{mgL}^{-1}$} & \multirow{2}{*}{$\begin{array}{l}\text { Total } \\
\text { N \% }\end{array}$} & \multirow{2}{*}{$\begin{array}{c}\mathbf{P} \\
\mathrm{mgkg}^{-1}\end{array}$} \\
\hline & & & & & & $\mathrm{Ca}^{+}$ & $\mathrm{Mg}^{+}$ & & $\mathrm{Hco}_{3}^{-}$ & $\mathrm{Cl}^{-}$ & So-"- & & \\
\hline 81 & 12 & 7 & Sandy & 0.15 & 8.2 & 0.64 & 0.46 & 0.22 & 0.51 & 0.38 & 0.61 & 0.11 & 1.6 \\
\hline
\end{tabular}

\section{Experimental Layout}

The experimental design was a randomized complete block design (RCBD) in the split plot system with three replicates. The salinity levels were allocated in the main plots at concentrations of $(500,1000$, and $1500 \mathrm{ppm})$ as sodium chloride $(\mathrm{NaCl})$ in water irrigation. In addition, to the control that was an application with tap water. Whereas the subplot units of each replicate were treated with Glutathione(GSH) $(25 \mathrm{mg}$ L.) and Selenium (Se) $(5 \mathrm{mg} \Lambda$.) as Sodium Selenite both as a foliar application, meanwhile Humic acid (HA) $(200 \mathrm{mg} / \mathrm{kg}$ soil) was incorporated into the potting media in addition to the control that was the foliar spray of distilled water. All treatments were added 4 times at 10 days intervals $(10,20,30$, and 40 days) after transplanting. On the other hand, in the third season, salinity levels were distributed in the main plots with concentrations $(500,1000$ and $1500 \mathrm{ppm})$ sodium chloride $(\mathrm{NaCl})$. In addition, to the control treatment that was an application with tap water. Meanwhile, in the sub-plots of the experimental units, the ameliorative treatments were used in coupled with the previous concentrations as follows: Glutathione and Selenium, Selenium and Humic acid and Glutathione and Humic acid.

\section{Sweet pepper cultivation}

Seven-week-old, sweet pepper seedlings were transplanted into plastic pots $35 \mathrm{~cm}$ inner diameter which filled with $15 \mathrm{~kg}$ sandy soil, on the $1^{\text {st }}$ of May 2018, 2019 and 2020 (Table1). Furthermore, sodium concentration was gradually increased, in order to avoid osmotic shock to growing sweet pepper seedlings. During all growing seasons, the amount of applied saline water was increased by $20 \%$ for leaching, to prevent salt accumulation and to maintain salinity as constant as possible throughout the whole season. After one week from saline treatment application, the foliar spray of Glutathione(GSH) $(25 \mathrm{mg} / \mathrm{L}$.) and Selenium (Se) $(5 \mathrm{mg} / \mathrm{L}$.) as Sodium Selenite were applied 4 times at 10- days intervals (10, 20, 30, and 40 days). Fertilization and all other recommended agricultural practices were applied as the national recommendation of the Ministry of Agriculture.

\section{Data recorded}

Vegetative growth characters:

After 70 days from planting, three random plants were chosen and the following measurements were carried out: leaves fresh weight per plant, leaves dry weight $(\mathrm{gm})$ and leaf area per plant $\left(\mathrm{cm}^{2}\right)$ calculated using the weight method as used by Fayed (1997).

\section{Leaf chlorophyll content}

Leave chlorophyll content was measured using a nondestructive dual-wavelength chlorophyll meter (SPAD-502, Minolta Corp., Ramsey, NJ, USA).

\section{Chemical composition:}

Leaf samples were oven dried at $70{ }^{\circ} \mathrm{C}$ for 48 hours and ground in a stainless steel mill blades. The wet digestion procedure was performed according to Chapman and Pratt (1978).

Nitrogen content in leaves was determined by the micro Kjeldahl method according to Page et al. (1982).

Phosphorus content was determined colorimetrically as reported by Jackson (1973).

Leaves $\mathrm{K}$ and $\mathrm{Na}$ contents were determined by flame photometer as illustrated by Horneck and Hanson (1998). Then the ratio of K/Na was calculated.

Determination of free proline content was carried out according to Bates (1973).

\section{The Yield and its components}

The fruit yield of sweet pepper was recorded at harvest time as fruit yield of sweet pepper plant $^{-1}(\mathrm{~g})$.

\section{Statistical analysis:}

All obtained records were statistically analyzed by using CoStat program (Version 6.4, CoHort, USA, 1998-2008). Least significant difference test $\left(\mathrm{LSD}_{0.05}\right)$ was applied at 0.05 confidence level to compare the different treatments means by using the same program.

\section{RESULTS AND DISCUSSION}

\section{Vegetative growth characters}

\section{Effect of salinity}

The main effects of salinity treatments on vegetative growth characters of sweet pepper plants in the three seasons presented in Tables 2 and 3 showed that all the measured growth parameters of sweet pepper plants namely: leaves fresh weight, leaves dry weight and leaf 
area plant ${ }^{-1}$ decreased generally in a stepwise fashion with increasing salinity stress, in the three seasons of study. Irrigation with water of the highest salinity level $(1500 \mathrm{ppm})$, resulted in reductions of $50.14,66.74$, and $31.92 \%$ in the first season and 44.51, 59.06 and $45.78 \%$ in the second season respectively. Meanwhile the reductions in the third season (Table 3) were 30.68, 43.00 and $39.03 \%$ for these characters, respectively compared to the control treatment. Such a reduction in growth could be attributed to the influence of high osmotic stress and ion toxicity (Hasanuzzaman et al., 2013) or due to the altered cell wall structure induced by salinity stress (Sekhon et al., 2010). Further, salinity stress might inhibit cell division, cell enlargement, and expansion resultantly production of new biomass shrunk as mentioned by Radi et al. (2013). These findings were generally noticed to coincide with those reported by Elkhatib et al. (2004) who found negative and significant effects of salinity stress on dry weight and leaves area of potato plants. Moreover, Yildirim et al. (2008) found that the salinity stress was associated with a noticeable depression in shoot fresh and dry weight, plant height and leaves number plant ${ }^{-1}$. These findings were supported also by Abdelaal et al. (2020) who found that a high concentration of salts in the irrigation water and soil accumulated around the roots of sweet pepper caused a significant decline of vegetation rate and growth performance.

Effect of of Glutathione, Selenium and Humic acid treatments:

The obtained data (Table 2 and 3) showed that Selenium, Glutathione and Humic acid treatments when used on sweet pepper plants either singly in the first and second seasons or in coupled in the third season, significantly increased vegetative growth parameters with different significant levels as compared to untreated plants followed by Glutathione. Meanwhile, Humic acid gave the lowest values. It was found that foliar spraying with selenium was superior and associated with the highest mean values of all vegetative growth traits on the first and second seasons compared to control treatment. The increasing percentages due to Selenium application over the control were estimated by $27.19,43.09$ and $40.20 \%$ in the first season and by $34.50,48.13$ and $46.46 \%$ in the second season for leaves fresh weight, leaves dry weight and leaf area plant ${ }^{-1}$, respectively compared to control treatment. Meanwhile, in the third season Selenium coupled with Glutathione was superior and associated with pronounced increments reached about $40.62,39.71$ and $21.31 \%$ for leaves fresh weight, leaves dry weight and leaf area plant $^{-1}$ respectively compared to control treatment .These results are in agreement with those found by Xue et al. (2001) and Simojoki et al. (2003) who found that Selenium treatments increased shoot and root biomass production in lettuce and it also increased the shoot dry

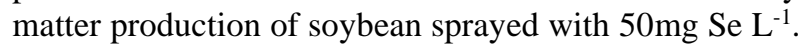
Furthermore, Ghoname et al. (2010) reported there were significant increases in vegetative growth parameters due to Glutathione treatments on hot pepper under the newly reclaimed sandy soil. Also Abd-Elhamid et al. (2018) mentioned that the increased growth by Glutathione can be attributed to the improved cell division of chickpea plants under salinity stress.

Table 2. Leaves fresh weight, leaves dry weight and leaf area of sweet pepper plants grown under salt stress as affected by Glutathione, Selenium and Humic acid treatments during 2018 and 2019 seasons

\begin{tabular}{|c|c|c|c|c|c|c|c|}
\hline \multirow[b]{2}{*}{ Treatments } & \multirow[b]{2}{*}{ Growth } & \multicolumn{3}{|c|}{ Season (2018) } & \multicolumn{3}{|c|}{ Season (2019) } \\
\hline & & $\begin{array}{c}\text { leaves fresh } \\
\text { weight (g) }\end{array}$ & $\begin{array}{c}\text { leaves } \\
\text { dry } \\
\text { weight } \\
\text { (g) } \\
\end{array}$ & $\begin{array}{c}\text { leaf area } \\
\left(\mathrm{cm}^{2}\right)\end{array}$ & $\begin{array}{l}\text { leaves } \\
\text { fresh } \\
\text { weight } \\
\text { (g) }\end{array}$ & $\begin{array}{c}\text { leaves } \\
\text { dry } \\
\text { weight } \\
\text { (g) }\end{array}$ & $\begin{array}{c}\text { leaf area } \\
\left(\mathrm{cm}^{2}\right)\end{array}$ \\
\hline \multirow{4}{*}{$\begin{array}{l}\text { Salinity levels } \\
\text { p.p.m }\end{array}$} & Control & $29.71 \mathrm{~A}$ & $12.87 \mathrm{~A}$ & $564.24 \mathrm{~A}$ & $34.20 \mathrm{~A}$ & $17.54 \mathrm{~A}$ & $597.29 \mathrm{~A}$ \\
\hline & 500 & $27.87 \mathrm{~A}$ & $10.08 \mathrm{~B}$ & $557.78 \mathrm{~A}$ & $30.17 \mathrm{~B}$ & $14.02 \mathrm{~B}$ & $496.00 \mathrm{~B}$ \\
\hline & 1000 & $22.82 \mathrm{~B}$ & $8.17 \mathrm{C}$ & $527.73 \mathrm{~B}$ & $22.27 \mathrm{C}$ & $12.24 \mathrm{C}$ & $366.05 \mathrm{C}$ \\
\hline & 1500 & $14.81 \mathrm{C}$ & $4.28 \mathrm{D}$ & $384.11 \mathrm{C}$ & $18.98 \mathrm{D}$ & $7.18 \mathrm{D}$ & $323.82 \mathrm{D}$ \\
\hline \multirow{4}{*}{$\begin{array}{l}\text { Ameliorative } \\
\text { Treatments }\end{array}$} & Control & $21.08 \mathrm{D}$ & $7.38 \mathrm{D}$ & $450.27 \mathrm{D}$ & $23.06 \mathrm{D}$ & $10.74 \mathrm{C}$ & $365.69 \mathrm{D}$ \\
\hline & $\begin{array}{l}\text { Glutathione } \\
(25 \mathrm{Mg} / \mathrm{L})\end{array}$ & $24.62 \mathrm{~B}$ & $9.44 \mathrm{~B}$ & $562.00 \mathrm{~B}$ & $27.14 \mathrm{~B}$ & $12.84 \mathrm{~B}$ & $464.82 \mathrm{~B}$ \\
\hline & $\begin{array}{l}\text { Selenium } \\
(5 \mathrm{mg} / \mathrm{L})\end{array}$ & $26.81 \mathrm{~A}$ & $10.56 \mathrm{~A}$ & $631.27 \mathrm{~A}$ & $31.01 \mathrm{~A}$ & $15.91 \mathrm{~A}$ & $535.60 \mathrm{~A}$ \\
\hline & $\begin{array}{l}\text { Humic acid } \\
(200 \mathrm{mg} / \mathrm{L})\end{array}$ & $22.71 \mathrm{C}$ & $8.02 \mathrm{C}$ & $490.32 \mathrm{C}$ & $24.40 \mathrm{C}$ & $11.50 \mathrm{C}$ & $417.06 \mathrm{C}$ \\
\hline
\end{tabular}

\footnotetext{
*The mean values with the same alphabetical letters do not significantly differ at $0.05 \%$ probability level.
} 
Table 3. Leaves fresh weight, leaves dry weight and leaves area of sweet pepper plants grown under salt stress as affected by glutathione \&selenium, selenium \& humic acid and glutathione \& humic acid during 2020 season

\begin{tabular}{lcccc}
\hline & Growth & \multicolumn{3}{c}{ Season $\mathbf{( 2 0 2 0})$} \\
\hline \multirow{2}{*}{ Treatments } & Control & $\begin{array}{c}\text { leaves fresh weight } \\
(\mathbf{g})\end{array}$ & $\begin{array}{c}\text { leaves dry weight } \\
(\mathbf{g})\end{array}$ & $\begin{array}{c}\text { leaf area } \\
\left(\mathbf{c m}^{\mathbf{2}}\right)\end{array}$ \\
\hline \multirow{3}{*}{ Salinity levels p.p.m } & 500 & $24.62 \mathrm{~A}$ & $16.61 \mathrm{~A}$ & $521.57 \mathrm{~A}$ \\
& 1000 & $20.17 \mathrm{~B}$ & $14.39 \mathrm{~B}$ & $425.31 \mathrm{~B}$ \\
& 1500 & $18.39 \mathrm{C}$ & $13.28 \mathrm{C}$ & $387.66 \mathrm{C}$ \\
& Control & $17.06 \mathrm{D}$ & $9.47 \mathrm{D}$ & $317.99 \mathrm{D}$ \\
Treatments & $17.11 \mathrm{D}$ & $11.13 \mathrm{D}$ & $371.95 \mathrm{D}$ \\
& glutathione \&selenium & $24.00 \mathrm{~A}$ & $15.55 \mathrm{~A}$ & $451.22 \mathrm{~A}$ \\
& selenium \& humic acid & $20.73 \mathrm{~B}$ & $14.51 \mathrm{~B}$ & $431.63 \mathrm{~B}$ \\
& glutathione \& humic acid & $18.41 \mathrm{C}$ & $12.56 \mathrm{C}$ & $397.75 \mathrm{C}$ \\
\hline
\end{tabular}

*The mean values with the same alphabetical letters do not significantly differ at $0.05 \%$ probability level.

\section{Effect of the interaction:}

Generally, the interaction between salinity levels and the ameliorative treatments was found to be significant for all the studied vegetative growth characters, in the three seasons of study (Figs. 1 - 9). Under the highest salinity level (1500 ppm $\mathrm{NaCl})$, Selenium treatment produced the highest significant interaction among the other ameliorative treatments of all vegetative characters followed by Glutathione in the first two seasons of study, which reflected the increments, in leaves fresh weight, leaves dry weight and leaf area plant $^{-1}$ by $67.41,56.77$ and $40.15 \%$ respectively in the first season and $47.84,62.45$ and $32.91 \%$, respectively in the second season, as compared to those plants grown under the same salinity level without protection treatment. Meanwhile, in the third season the combined effect of Selenium and Glutathione was more pronounced compared to other combinations and their increment values were $48.00,52.12$ and $21.71 \%$ for leaves fresh weight, leaves dry weight and leaf area plant $^{-1}$ respectively, as compared to control treatment. Similar findings were stated by Abul-Soud and AbdElrahman (2016) who reported that Se application (20 $\mathrm{M})$ in the form of sodium selenite caused improvements in the growth and yield of eggplants under varying levels of soil salinity. Likewise, Astaneh et al. (2019) suggested that growth parameters such as the bulb height, fresh and dry biomass of bulbs, bulb diameter, and the number of cloves bulb ${ }^{-1}$ of Garlic (Allium Sativum L.) were significantly improved with the addition of Se under salinity stress. On the other hand, Hemmat (2007) confirmed that exogenous application of Glutathione mitigated partially or completely the adverse effects of salt stress on the growth of Canola seedlings. Furthermore, Nahar et al. (2015) reported that applications of exogenous GSH promoted plant growth and improved stress tolerance by detoxifying stressinduced ROS in mung bean plants.

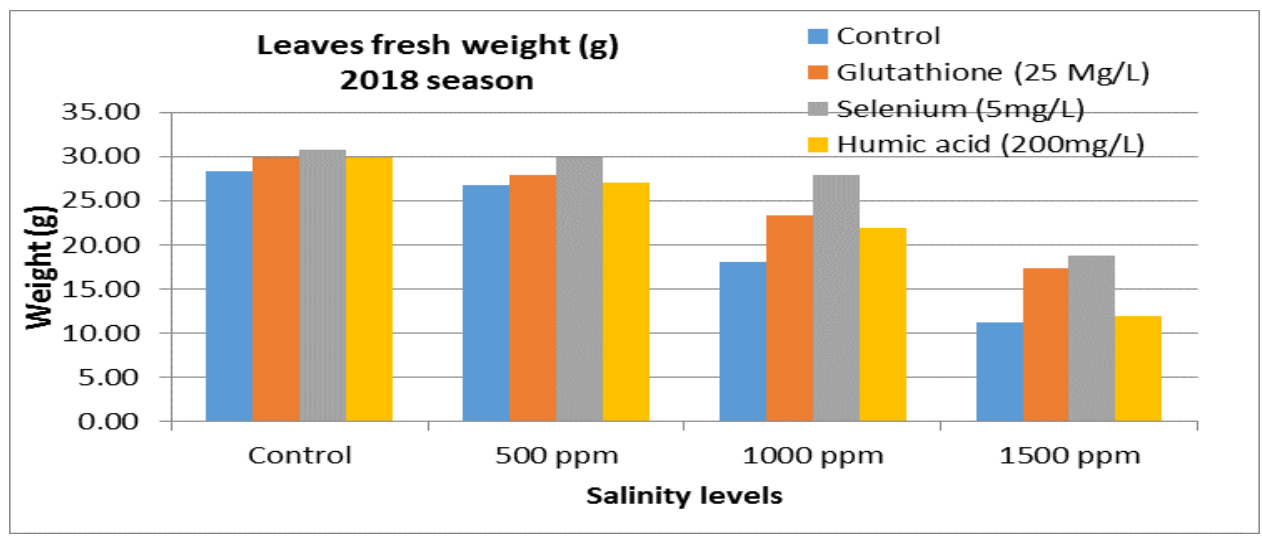

Fig. 1. Leaves fresh weight of sweet pepper plants under different salinity levels in response to Glutathione, Selenium and Humic acid treatments during 2018 season 


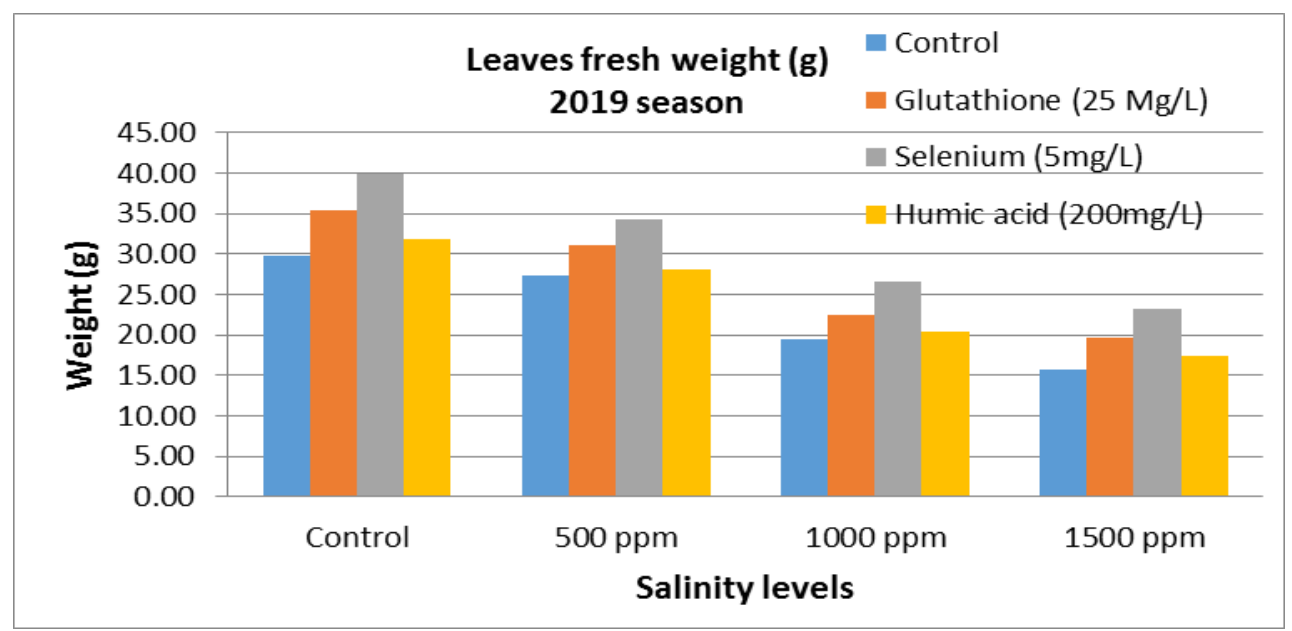

Fig. 2. Leaves fresh weight of sweet pepper plants under different salinity levels in response to Glutathione, Selenium and Humic acid treatments during 2019 season

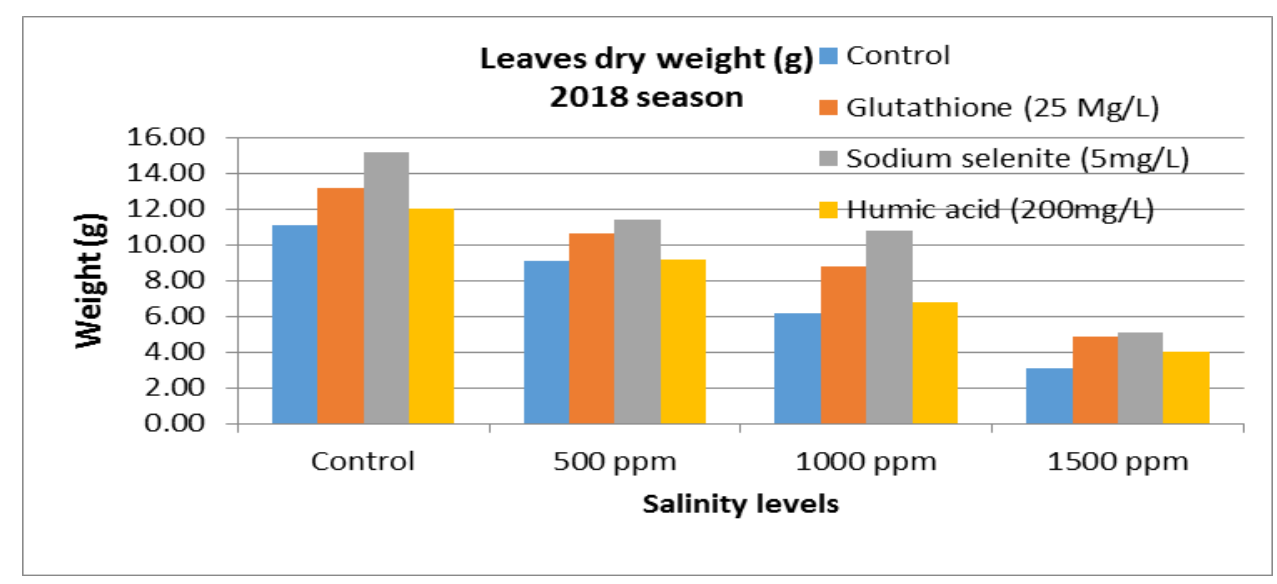

Fig. 3. Leaves dry weight of sweet pepper plants under different salinity levels in response to Glutathione, Selenium and Humic acid treatments during 2018 season

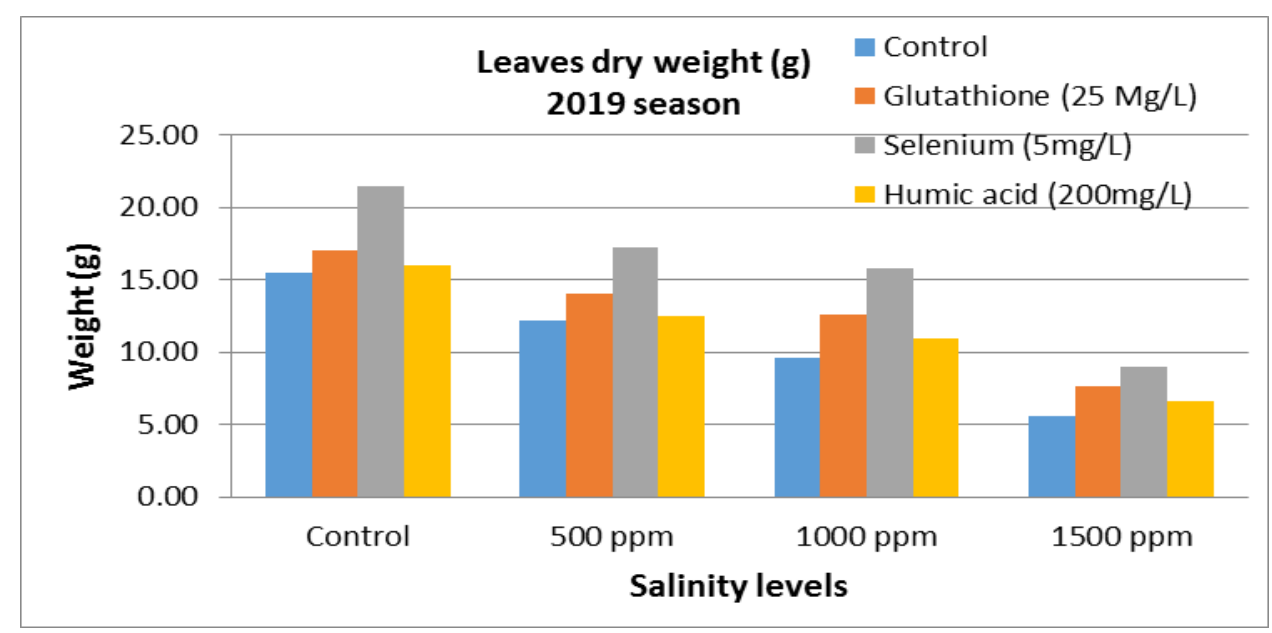

Fig.4. Leaves dry weight of sweet pepper plants under different salinity levels in response to Glutathione, Selenium and Humic acid treatments during 2019 season 


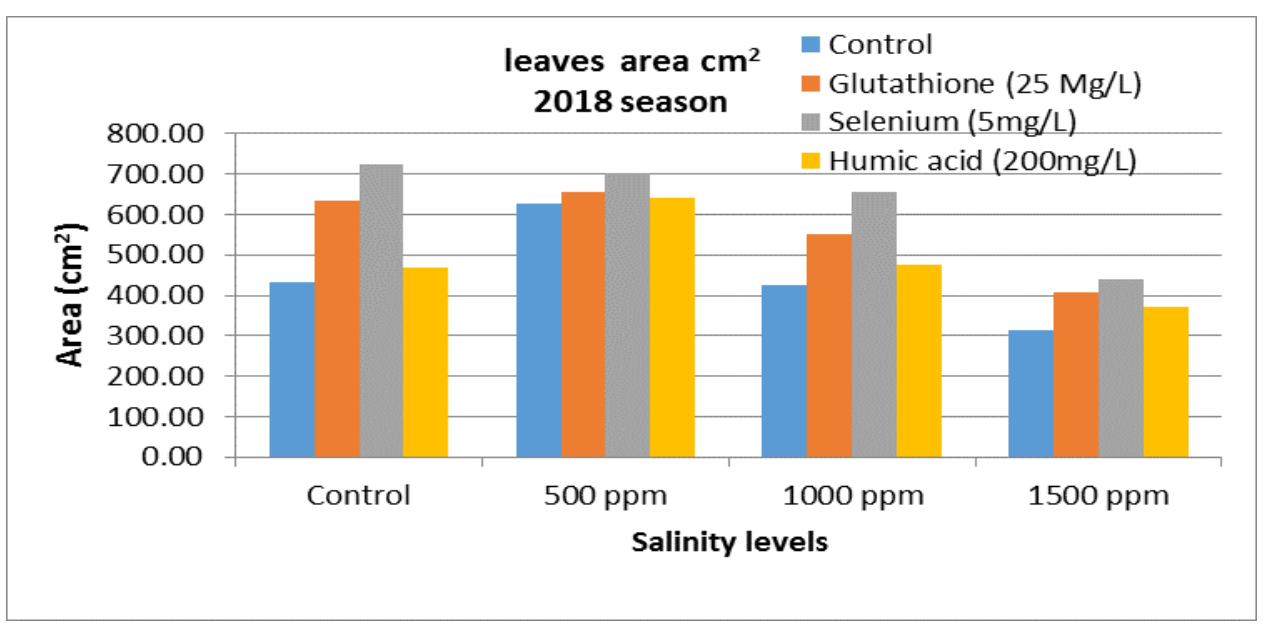

Fig. 5. Leaf area of sweet pepper plants under different salinity levels in response to Glutathione, Selenium and Humic acid treatments during 2018 season

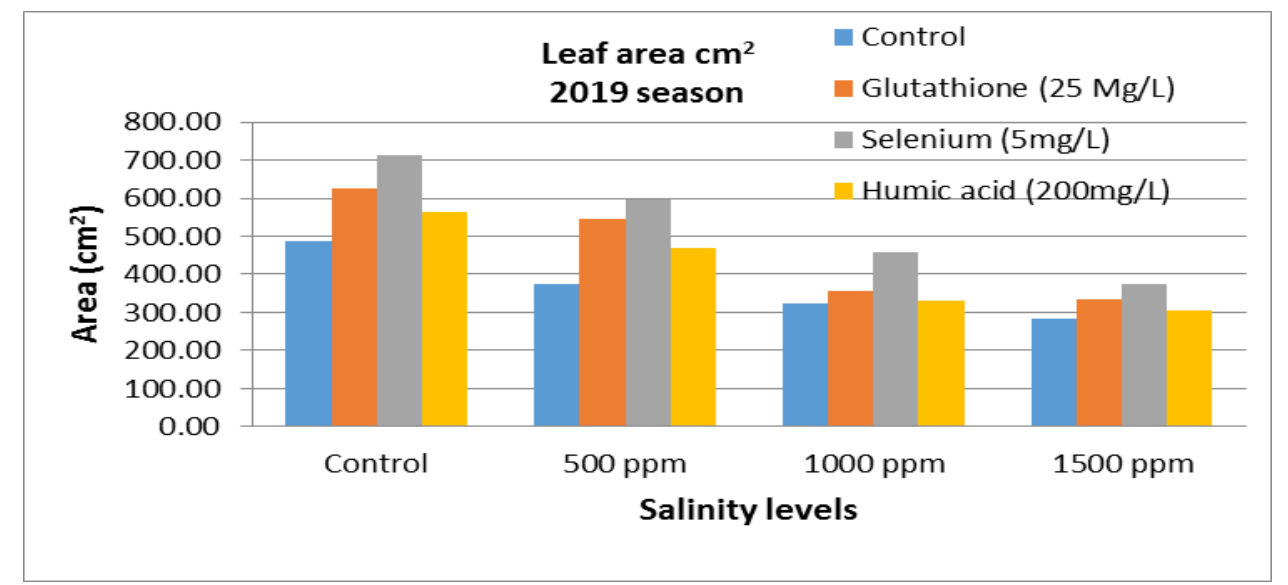

Fig. 6. Leaf area of sweet pepper plants under different salinity levels in response to Glutathione, Selenium and Humic acid treatments during 2019 season

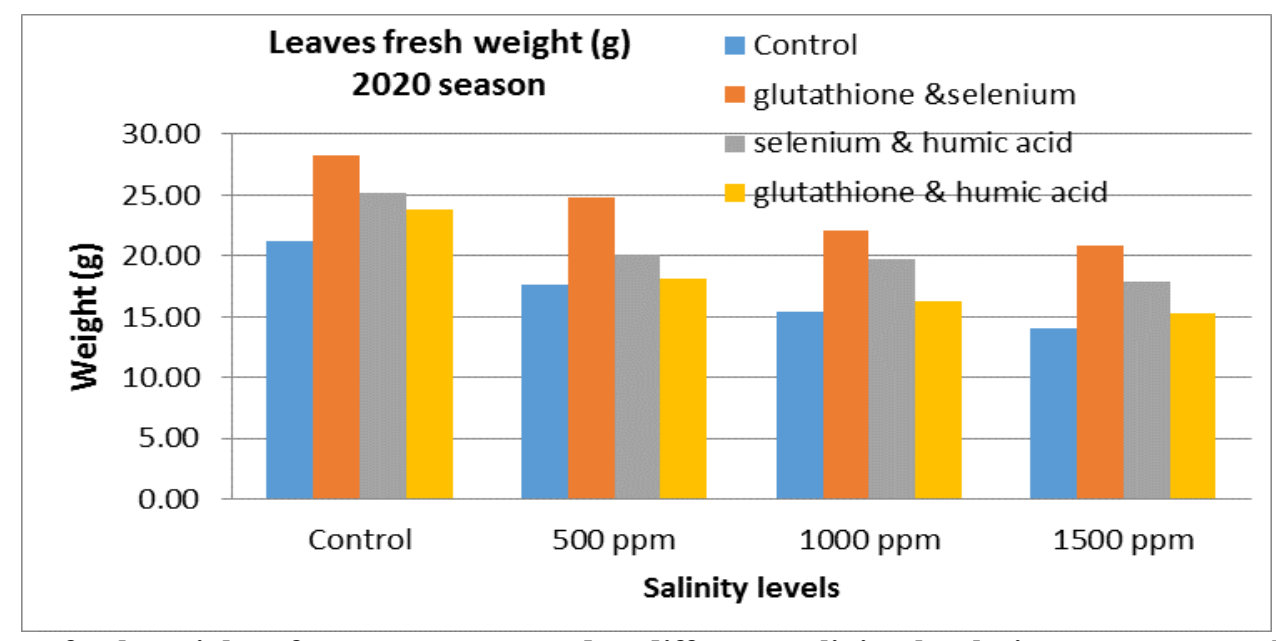

Fig. 7. Leaves fresh weight of sweet pepper under different salinity levels in response to glutathione \& selenium, selenium \& humic acid and glutathione\& humic acid treatments during 2020 season 


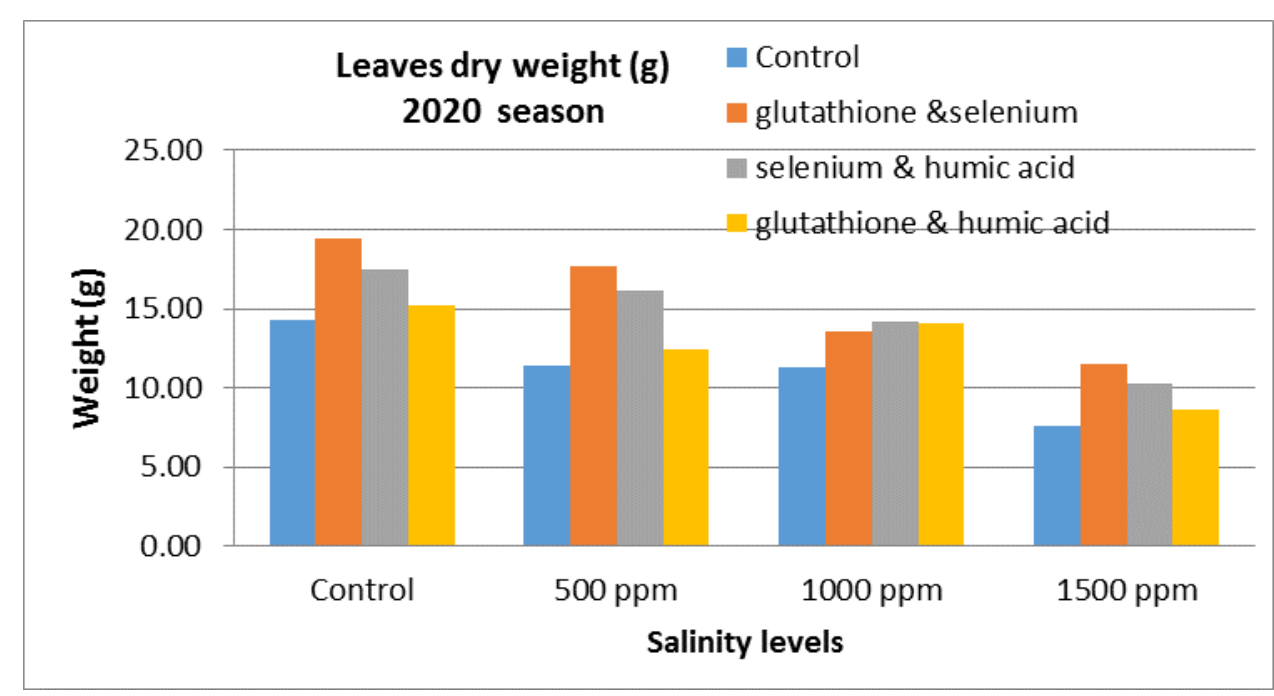

Fig. 8. Leaves dry weight of sweet pepper plants under different salinity levels in response to glutathione\&selenium, selenium \& humic acid and glutathione\& humic acidtreatment during 2020 season

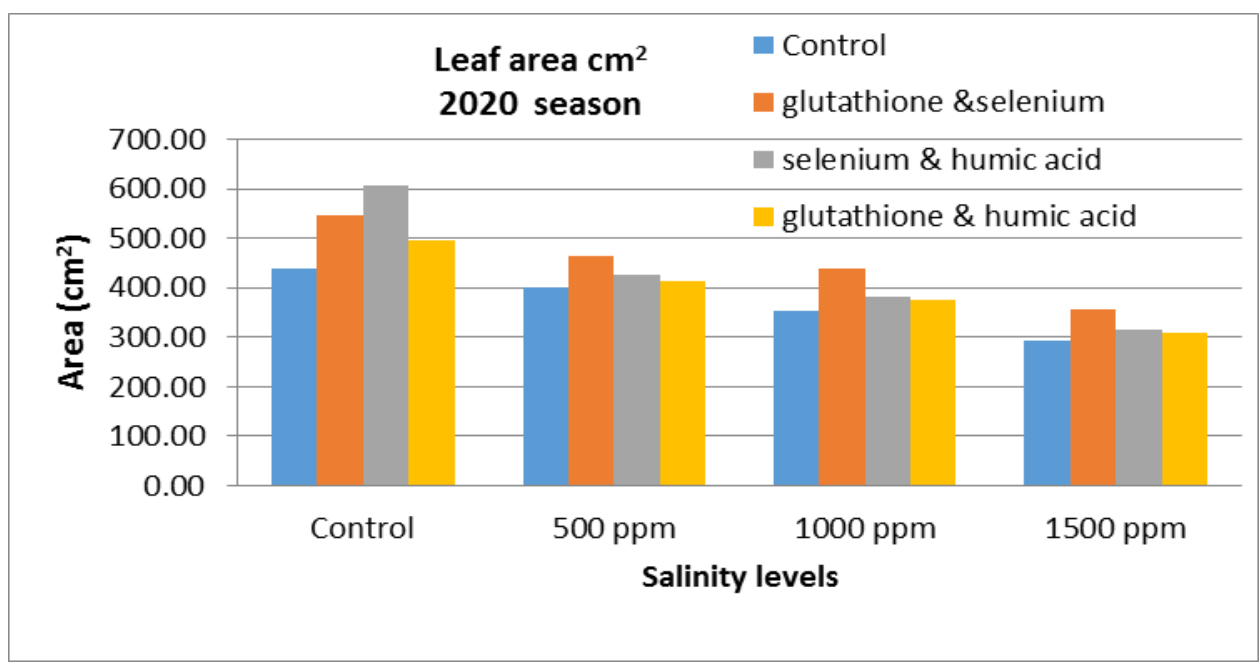

Fig. 9. eaves area of sweet pepper plants under different salinity levels in response to glutathione\& selenium, selenium\& humic acid and glutathione \& humic acid treatment during 2020 season

\section{Chlorophyll contents}

Effect of salinity:

Tables 4 and 5 showed that salt stress had a significant noticeable reducing effect on chlorophyll content of sweet pepper plants. The relative reductions in chlorophyll content in the three seasons of study at the highest salinity level $(1500 \mathrm{ppm} \mathrm{Na} \mathrm{Cl})$ as percentages of the corresponding values of control were $30.27,28.39,31.61 \%$ respectively. These findings are in agreement with the results found by Ghosh et al. (2001) and Faried et al. (2016) who found a remarkable effect of salinity stress on decreasing the potato leaves content of photosynthetic pigments. Also the results achieved by
Franken et al. (2014) stated that salinity can affect photosynthesis via reducing chlorophyll content, destruction of chloroplast ultrastructure, or damaging many of the related enzymes.

Effect of Glutathione, Selenium and Humic acid treatments:

The main effect of ameliorative treatments was found to be significant for chlorophyll pigment contents of sweet pepper leaves, when used either singly in the first and second seasons or in coupled in the third season of study (Tables 4 and 5). Selenium was the most effective treatment in the first two seasons of study for chlorophyll contents with increment percentages 
estimated by $30.58 \%$ and $31.64 \%$, respectively over control. Meanwhile, in the third season the best valuable combination was Selenium coupled with Glutathione treatment with the percentage increments of $29.55 \%$ compared to control treatment. Similar findings were obtained by Hawrylak- Nowak (2008) who found that, Se treatments at 5 and $10 \mu \mathrm{M}$ significantly increased the photosynthetic pigment contents in cucumber leaves. Furthermore, Duma et al. (2011) illustrated that, lettuce plants (Lactuca sativa) treated with selenium had higher leaves photosynthetic pigment (chlorophyll and carotenoids) content in comparison to untreated ones. On the other hand, Exogenous Glutathione protects tomatoes against salt stress by modulating photosystem II efficiency, and $\mathrm{H}_{2} \mathrm{O}_{2}$ scavenging system in chloroplasts thus increasing tomato resistance to the damaging oxidative effects of salt stress (Zhou et al. 2017).

\section{Effect of the interaction:}

Concerning the interaction effects between salinity and ameliorative treatments, the recorded results clarified significant positive effects on chlorophyll contents on both seasons (Figures 10-12). The best valuable interactions were obtained from the treatments of Selenium application either singly or coupled with Glutathione at all salinity levels on the three seasons of study. Similarly, Wang et al. (2012) found increased photosynthesis in rice seedlings at low doses of Se. Also the results achieved by Alsina et al. (2012) confirmed an increase in lettuce pigments as a result of Se application. Also Ghasemi et al. (2016) observed significant increases in chlorophyll contents as a result of Se treatments.

Table 4. Total chlorophyll content in leaves of sweet pepper plants grown under salt stress as affected by Glutathione, Selenium and Humic acid treatments during 2018 and 2019 seasons

\begin{tabular}{cccc}
\hline & & Season (2018) & Season (2019) \\
\hline Factors & Growth & Total cha. & Total cha. \\
\hline \multirow{3}{*}{ Salinity levels p.p.m } & Control & $55.21 \mathrm{~A}$ & $56.83 \mathrm{~A}$ \\
& 500 & $50.25 \mathrm{~B}$ & $51.35 \mathrm{~B}$ \\
& 1000 & $45.88 \mathrm{C}$ & $46.07 \mathrm{C}$ \\
& 1500 & $38.50 \mathrm{D}$ & $40.69 \mathrm{D}$ \\
Treatments & Control & $41.25 \mathrm{D}$ & $43.38 \mathrm{D}$ \\
& Glutathione $(25 \mathrm{Mg} / \mathrm{L})$ & $50.18 \mathrm{~B}$ & $48.98 \mathrm{~B}$ \\
& Selenium $(5 \mathrm{mg} / \mathrm{L})$ & $53.86 \mathrm{~A}$ & $57.11 \mathrm{~A}$ \\
& Humic acid $(200 \mathrm{mg} / \mathrm{L})$ & $44.55 \mathrm{C}$ & $45.47 \mathrm{C}$ \\
\hline
\end{tabular}

*The mean values with the same alphabetical letters do not significantly differ at $0.05 \%$ probability level.

Table 5. Total chlorophyll content in leaves of sweet pepper plants grown under salt stress as affected by glutathione \&selenium, selenium \& humic acid and glutathione \& humic acid during 2020 season

\begin{tabular}{lcc}
\hline & & Season (2020) \\
\hline Factors & Growth & Total cha. \\
\hline \multirow{2}{*}{ Salinity levels p.p.m } & Control & $55.77 \mathrm{~A}$ \\
& 500 & $48.36 \mathrm{~B}$ \\
& 1000 & $41.09 \mathrm{C}$ \\
Treatments & 1500 & $38.14 \mathrm{D}$ \\
& Control & $39.93 \mathrm{D}$ \\
& glutathione \&selenium & $51.73 \mathrm{~A}$ \\
\hline
\end{tabular}

\footnotetext{
*The mean values with the same alphabetical letters do not significantly differ at $0.05 \%$ probability level.
} 


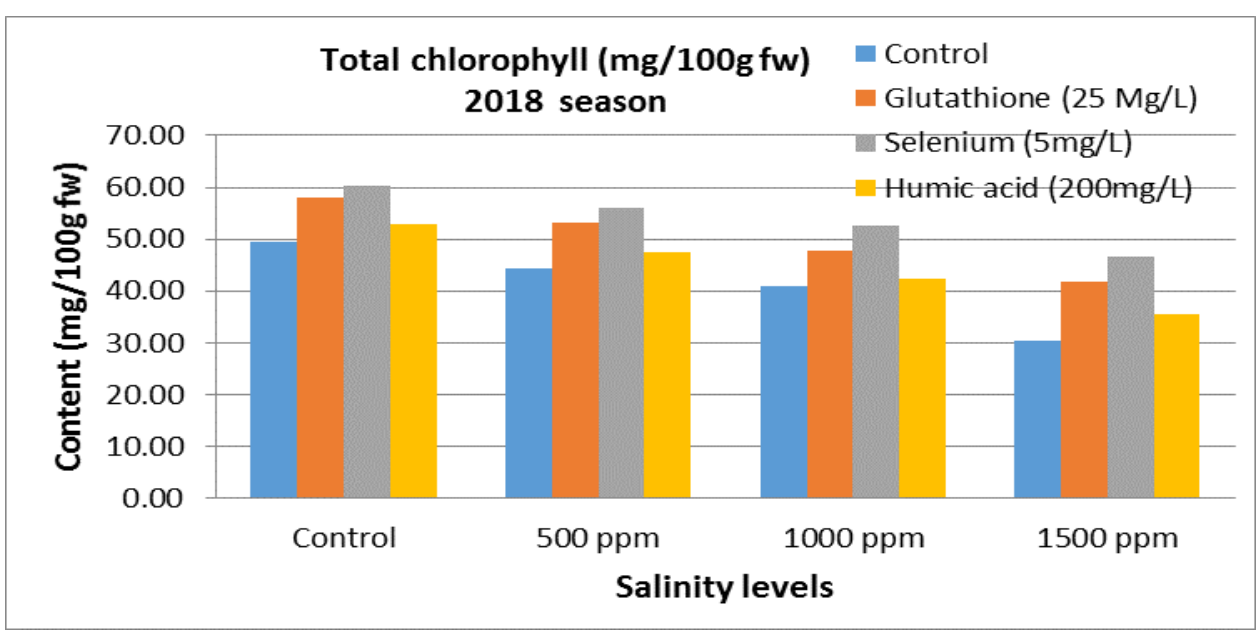

Fig. 10. Total chlorophyll contents in sweet pepper leaves under different salinity levels in response to Glutathione, Selenium and Humic acid treatments during 2018 and season

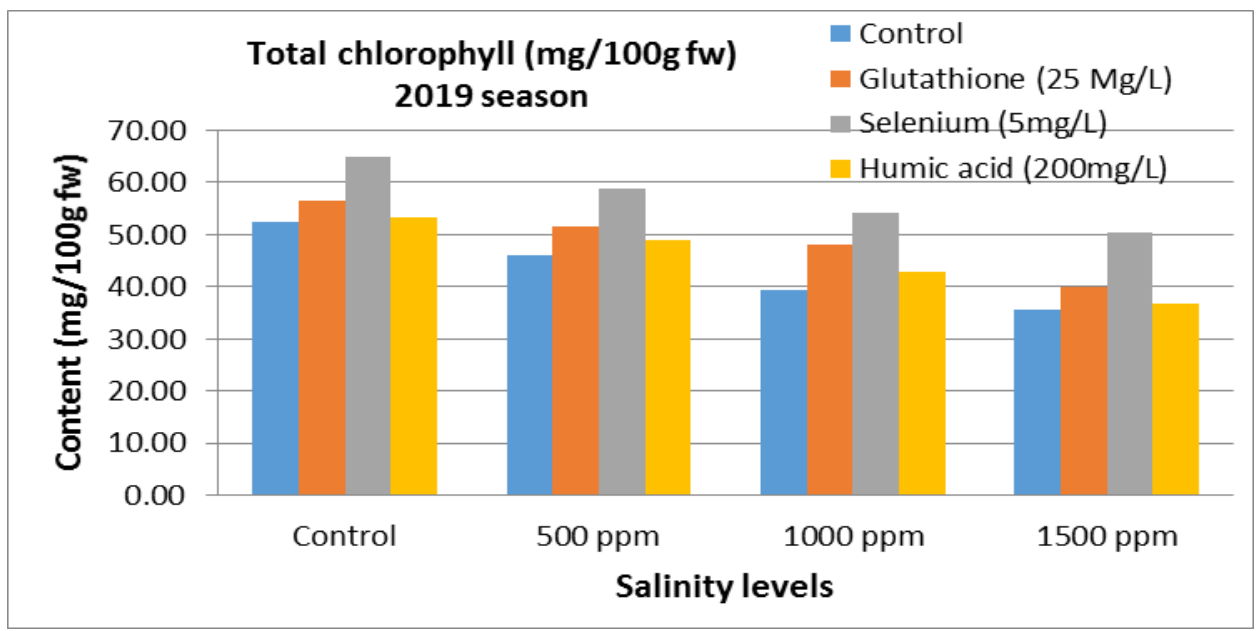

Fig. 11. Total chlorophyll contents in sweet pepper leaves under different salinity levels in response to Glutathione, Selenium and Humic acid treatments during and 2019 season

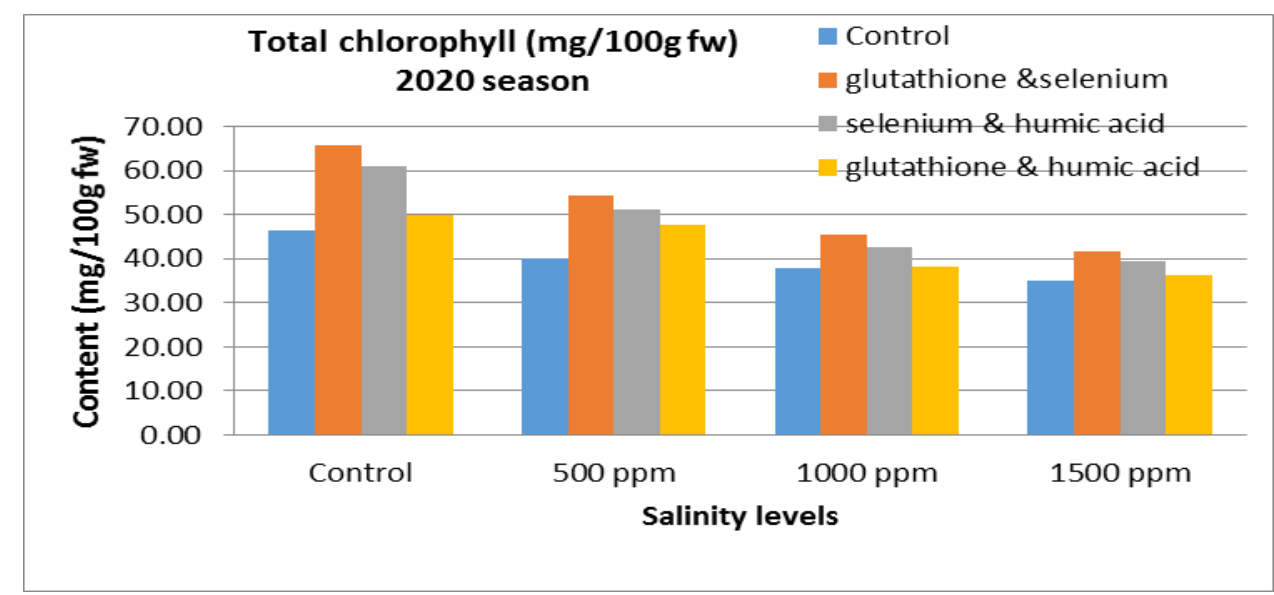

Fig. 12. Total chlorophyll contents in sweet pepper leaves under different salinity levels in response to glutathione \&selenium, selenium \& humic acid and glutathione\& humic acid treatment during 2020 season 


\section{Chemical composition}

\section{Effect of salinity:}

Nitrogen, Phosphorus and Calcium contents:

Tables 6 and 7 indicated that N, P and Ca contents in leaves of sweet pepper significantly decreased with increasing salinity level in the three seasons compared with the control. The percentages of decreasing due to $1500 \mathrm{ppm}$ salinity treatment compared with control were $43.54 \%, 26.63$ and $30.18 \%$ for $\mathrm{N} ; 54.43,34.0$ and $29.09 \%$ for P; 31.58, 24.28 and $48.48 \%$ for Ca. These results of this investigation were in agreement with those of Ghosh et al. (2001) and Faried et al. (2016) who found remarkable effects of salinity stress on decreasing the potato leaves of different nutrient contents. Similar findings were found by El-Folly et al. (2000) who was reported that macronutrients (N, P, K, $\mathrm{Mg}$, and $\mathrm{Ca}$ ) uptake were negatively affected by increasing $\mathrm{NaCl}$ in the growth root medium under saline conditions. Numerous reports indicated that salinity reduces nutrient uptake and accumulation of nutrients in the plants (Rogers et al.2003; Hu and Schmidhalter 2005). Decreased N uptake under saline conditions occurs due to interaction between $\mathrm{Na}^{+}$and $\mathrm{NH}_{4}{ }^{+}$that ultimately reduce the growth and yield of the crop (Debouba et al.2006). Qadir and Schubert (2002) reported that the availability of $\mathrm{P}$ was reduced in saline soils due to ionic strength effects that reduced the activity of $\left(\mathrm{PO}_{4}\right)^{-3}$, and low solubility of Ca-P minerals which resulted in decreased phosphate concentration by increasing salinity level.

Effect of of Glutathione, Selenium and Humic acid treatments:

Tables 6 and 7 showed that Selenium, Glutathione and Humic acid treatments when used singly in the first and second seasons or in coupled in the third season, significantly increased $\mathrm{N}, \mathrm{P}$ and $\mathrm{Ca}$ contents with different significant levels when compared to untreated

Table 6. Nitrogen, phosphorus and calcium content in leaves of sweet pepper plants grown under salt stress as affected by Glutathione, Selenium and Humic acid treatments during 2018 and 2019 seasons

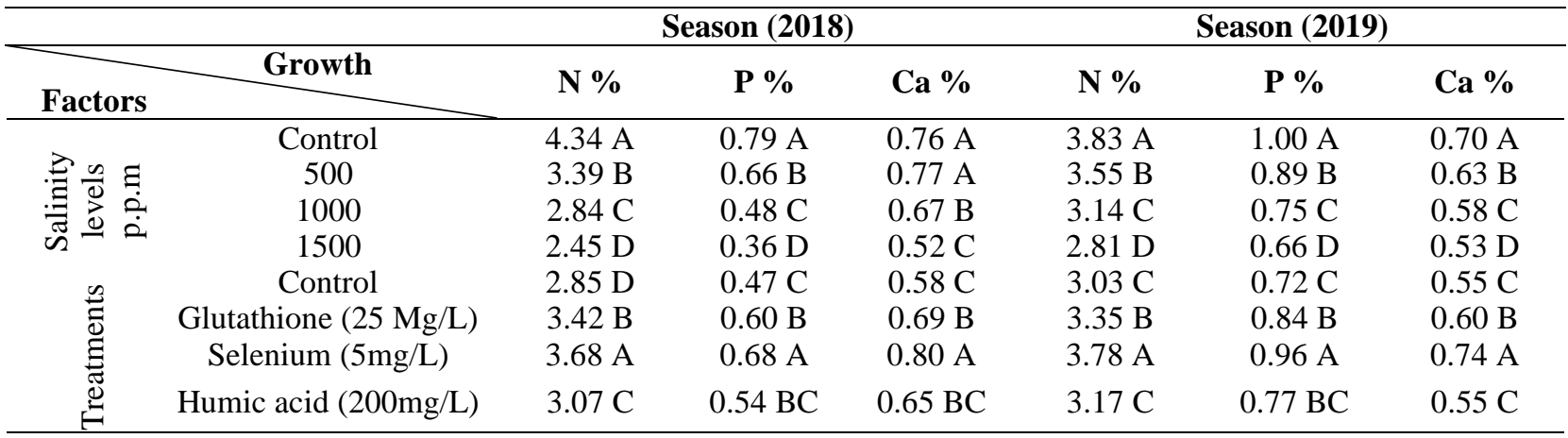

*The mean values with the same alphabetical letters do not significantly differ at $0.05 \%$ probability level.

Table 7. Nitrogen, phosphorus and calcium content in leaves of sweet pepper plants grown under salt stress as affected by glutathione \&selenium, selenium \& humic acid and glutathione \& humic acid treatments during 2020 season

\begin{tabular}{lcccc}
\hline & & \multicolumn{3}{c}{ Season (2020) } \\
\hline Factors & Growth & N \% & P \% & Ca \% \\
\hline Salinity levels p.p.m & Control & $3.81 \mathrm{~A}$ & $1.10 \mathrm{~A}$ & $0.99 \mathrm{~A}$ \\
& 500 & $3.47 \mathrm{~B}$ & $1.05 \mathrm{~B}$ & $0.76 \mathrm{~B}$ \\
& 1000 & $3.16 \mathrm{C}$ & $0.91 \mathrm{C}$ & $0 . .64 \mathrm{C}$ \\
Treatments & 1500 & $2.66 \mathrm{D}$ & $0.78 \mathrm{D}$ & $0.51 \mathrm{D}$ \\
& Control & $2.65 \mathrm{C}$ & $0.78 \mathrm{C}$ & $0.74 \mathrm{C}$ \\
& glutathione \&selenium & $3.80 \mathrm{~A}$ & $1.12 \mathrm{~A}$ & $1.08 \mathrm{~A}$ \\
& selenium \& humic acid & $3.61 \mathrm{~A}$ & $1.06 \mathrm{~A}$ & $0.98 \mathrm{~B}$ \\
& glutathione \& humic acid & $3.03 \mathrm{~B}$ & $0.89 \mathrm{~B}$ & $0.83 \mathrm{C}$ \\
\hline
\end{tabular}

\footnotetext{
*The mean values with the same alphabetical letters do not significantly differ at $0.05 \%$ probability level.
} 
plants. Treated sweet pepper plants with Selenium singly in the first and the second seasons or coupled with Glutathione in the third season achieved higher N, $\mathrm{P}$ and $\mathrm{Ca}$ contents estimated by 29.12, 44.68 and $37.93 \%$ in the first season, $24.75,33.33$ and $34.55 \%$ in the second season and 43.58, 34.54 and $45.94 \%$ in the third season respectively. These findings were emphasized by Gul et al. (2017) who suggested that selenium applied at $10 \mathrm{mM}$ showed better performance on different biochemical attributes in both saline and non-saline conditions. On the other hand, Noctor et al. (2012) reported that the importance of Glutathione is due to its role in different biosynthetic pathways, detoxification process and antioxidant biochemistry.

\section{Effect of the interaction:}

The interaction effects of Ameliorative treatments and salinity levels on $\mathrm{N}, \mathrm{P}$ and $\mathrm{Ca}$ contents were significant in the three seasons. Ameliorative treatments significantly increased $\mathrm{N}, \mathrm{P}$ and $\mathrm{Ca}$ contents of sweet pepper leaves under different salinity levels, but with different magnitudes (Figs 13-21). At the highest salinity level $(1500 \mathrm{ppm})$, data revealed that Selenium increased $\mathrm{N}, \mathrm{P}$ and $\mathrm{Ca}$ contents of sweet pepper leaves by $31.31,32.26$ and $25.53 \%$ in the first season and by $23.53,23.33$ and $45.65 \%$ respectively in the second season compared to the control. Also Selenium coupled with Glutthione application at $1500 \mathrm{ppm}$ salinity level increased N, P and Ca contents by 45.58, 46.03 and 55.0 $\%$ respectively in the third season compared to the control (Figs 19-21). Similar finding by Boghdady et al. (2017) revealed that plants treated with $10 \mathrm{mgL}^{-1}$ selenium gave a significant increase of $\mathrm{N}, \mathrm{P}$ and $\mathrm{K}$ percentages in seeds of faba bean plants

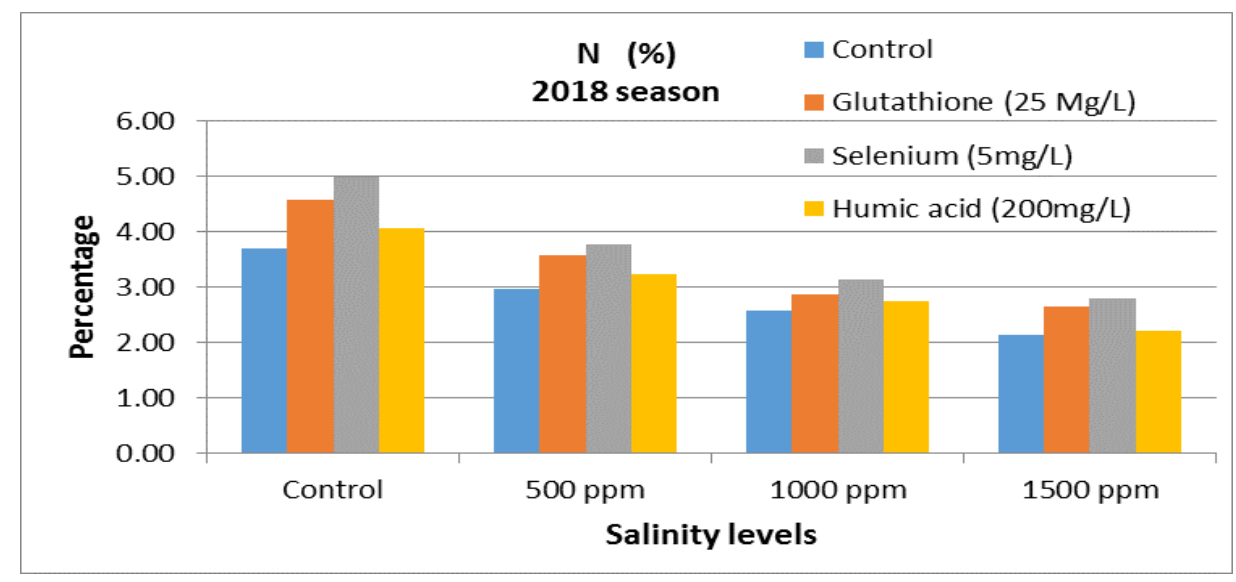

Fig. 13. Nitrogen content in sweet pepper leaves under different salinity levels in response to Glutathione, Selenium and Humic acid treatments during 2018 and season

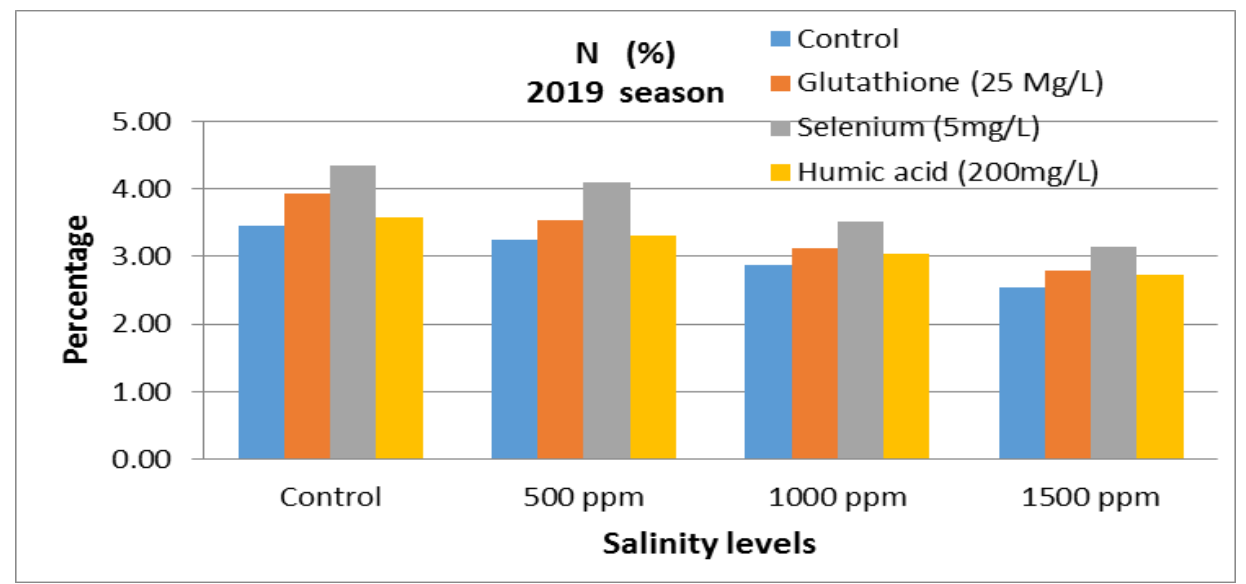

Fig. 14. Nitrogen content in sweet pepper leaves under different salinity levels in response to Glutathione, Selenium and Humic acid treatments during 2019 season 


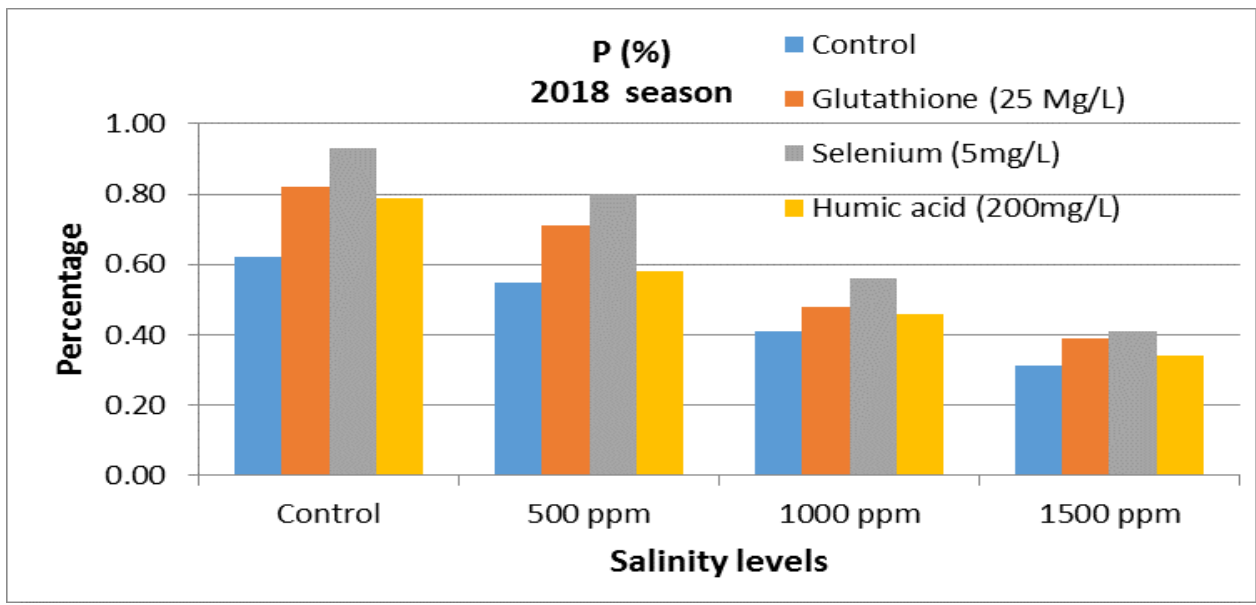

Fig. 15. Phosphorus content in sweet pepper leaves under different salinity levels in response to Glutathione, Selenium and Humic acid treatments during 2018 and season

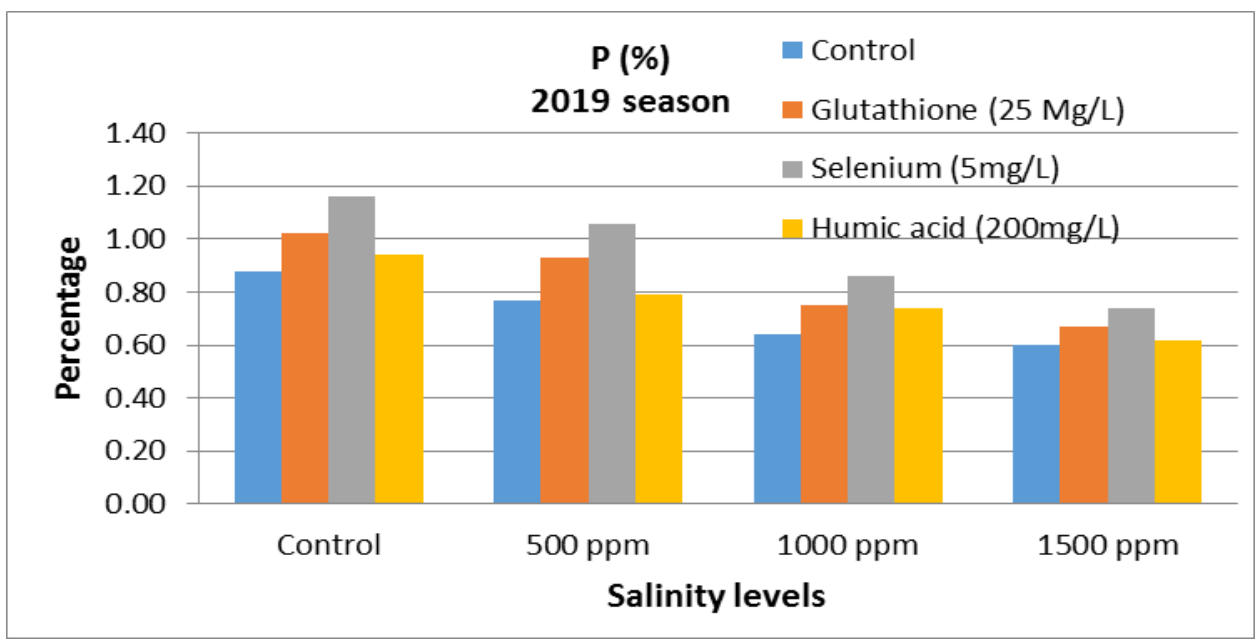

Fig. 16. Phosphorus content in sweet pepper leaves under different salinity levels in response to Glutathione, Selenium and Humic acid treatments during 2019 season

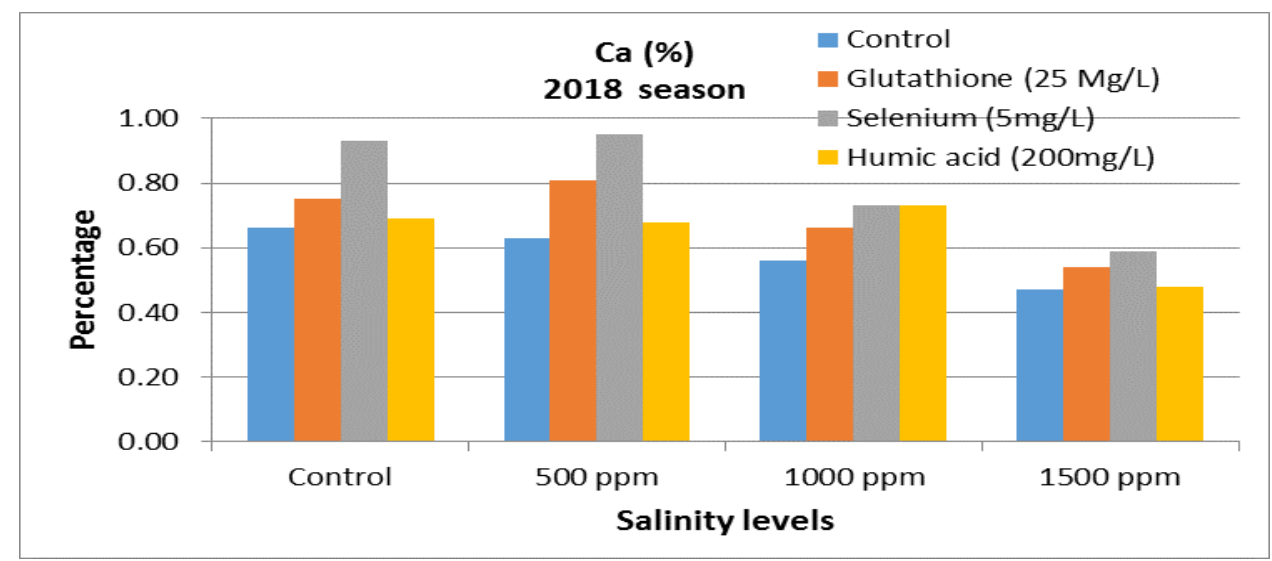

Fig. 17. Calcium content in sweet pepper leaves under different salinity levels in response to Glutathione, Selenium and Humic acid treatments during 2018 season 


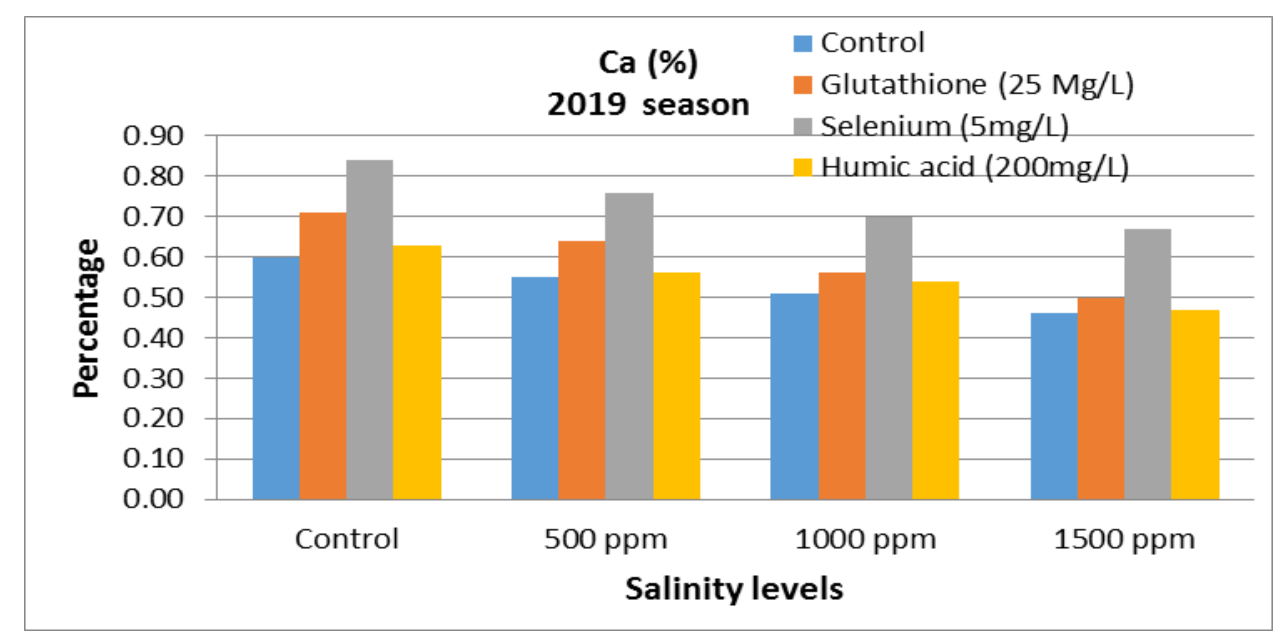

Fig.18. Calcium content in sweet pepper leaves under different salinity levels in response to Glutathione, Selenium and Humic acid treatments during 2019 season

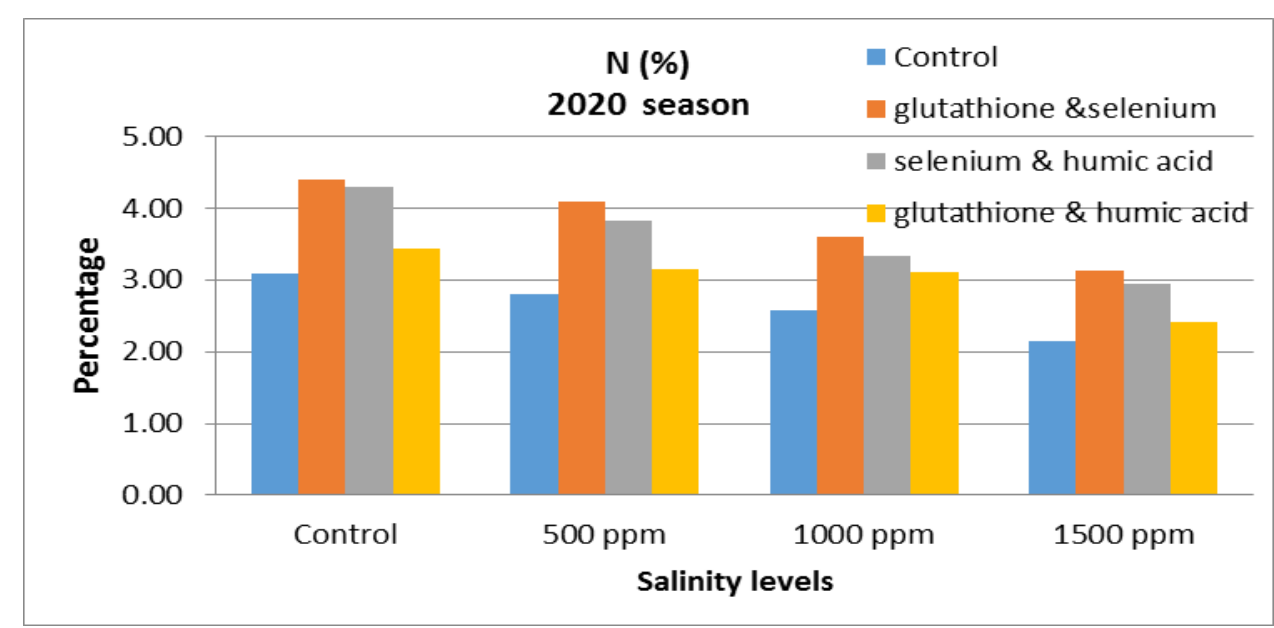

Fig. 19. Nitrogen accumulation in sweet pepper leaves under different salinity levels in response to glutathione \& selenium, selenium \& humic acid and glutathione\& humic acid treatment during 2020 season

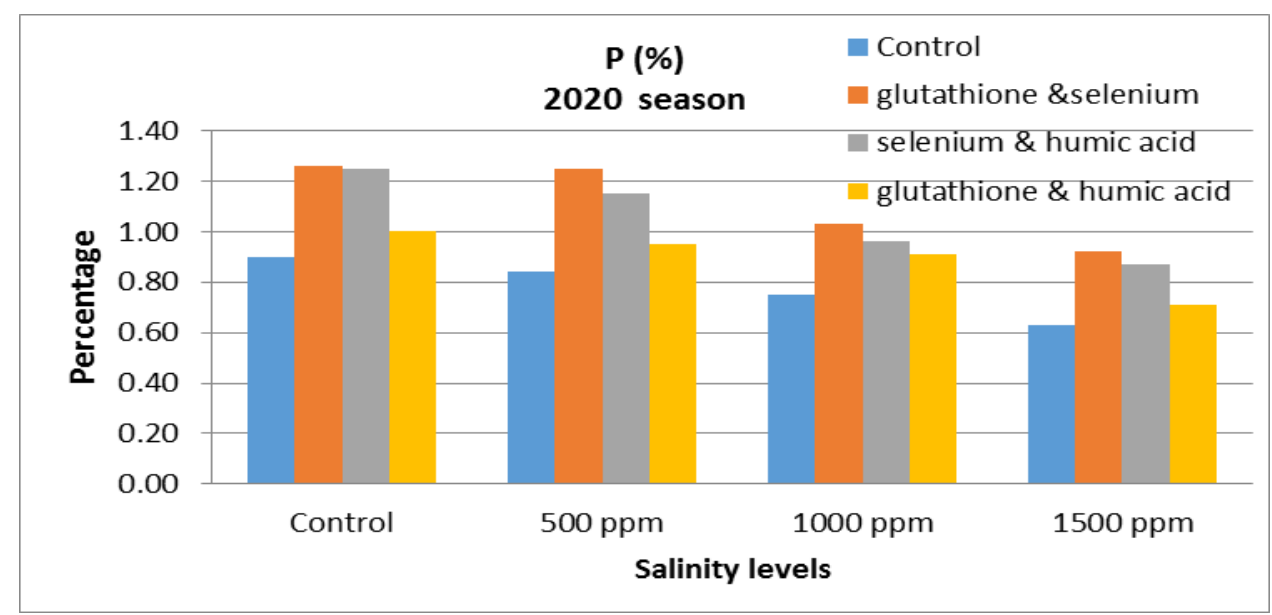

Fig. 20. Phosphorus content in sweet pepper leaves under different salinity levels in response to glutathione \&selenium, selenium \& humic acid and glutathione\& humic acid treatments during 2020 season 


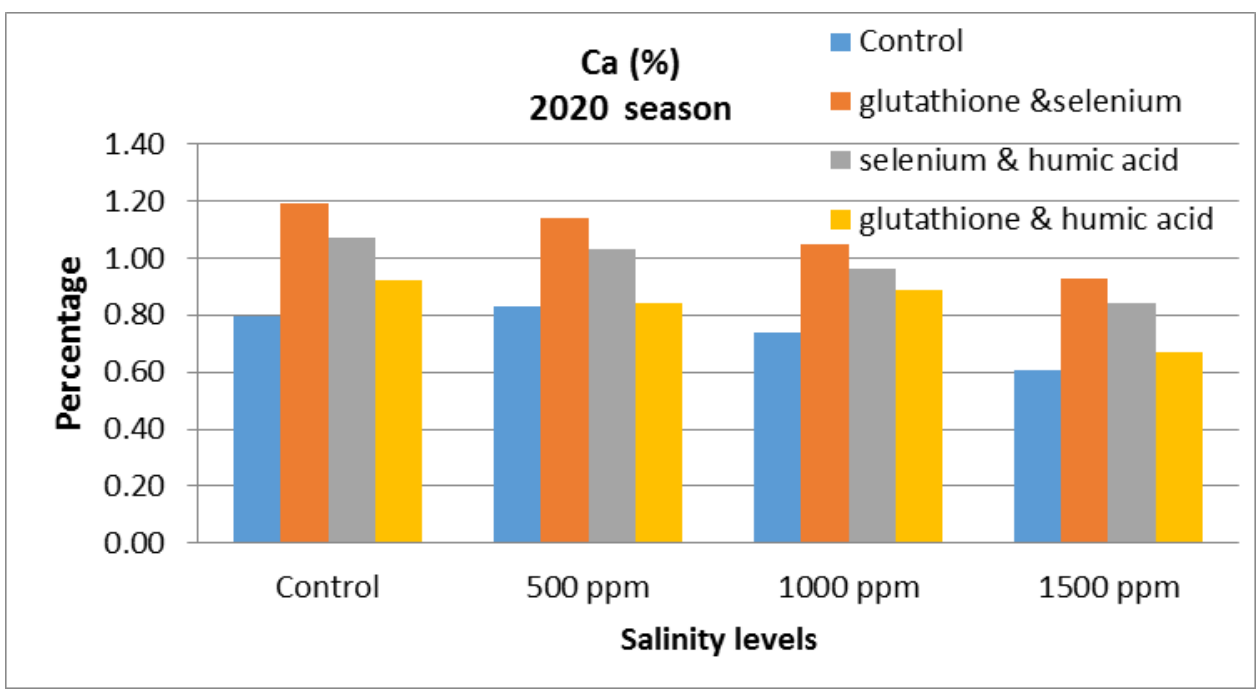

Fig. 21. Calcium content in sweet pepper leaves under different salinity levels in response to glutathione $\&$ selenium, selenium \& humic acid and glutathione\& humic acid treatments during 2020 season

\section{Potassium, Sodium, Proline contents and K/Na ratio: Effect of salinity:}

Tables 8 and 9 showed that salinity stress significantly increased proline and $\mathrm{Na}$ contents but reflected a reversal trend to that of $\mathrm{Na}$ and proline where decreased $\mathrm{K}$ content and $\mathrm{K} / \mathrm{Na}$ ratio with increasing salinity level in leaves of sweet pepper plants of all the three seasons of study. Therefore, the irrigation by high level of salinity $(1500 \mathrm{ppm})$ gave the highest values of sodium and proline contents in leaves which reached 6.75,6.2 and 5.57 times of control for sodium and 2.5, 1.9 and 3.34 times of the control for proline in the first, second and third seasons respectively. On the other hand, the decrements of $\mathrm{K}$ were $16.37,18.62$ and 22.94 $\%$ in the first, second and third seasons respectively, compared to control treatment. It can therefore be concluded that salinity induces proline accumulation in leaves of sweet pepper plants to maintain osmotic and ionic balance. The obtained results seemed also to be in accordance with those obtained by Babu et al. (2012) who mentioned that the increasing of $\mathrm{Na}$ content and decreasing of $\mathrm{K}$ contents and $\mathrm{K} / \mathrm{Na}$ ratio caused confection in ion homeostasis which affected negatively the osmotic potential of cells that adversely affected plants' growth and development under salinity stress. The higher concentration of proline under salt stress is favorable to plants as proline participate to osmotic potential of leaf and thus to osmotic adjustment (Hasegawaet al., 2000). In addition Sivasankaramoorthy et al. (2010) reported that proline and free amino acids act as compatible solutes to protect the cellular macromolecules which are functioning in maintaining the osmotic balance and also scavenge the free radicals.

\section{Effect of of Glutathione, Selenium and Humic acid treatments:}

Concerning the effects of Glutathione, Selenium and Humic acid treatments (Tabes 8-9) the obtained result generally, indicated that the applied protection treatments (Glutathione, Selenium and Humic acid) significantly increased $\mathrm{K}$ and $\mathrm{K} / \mathrm{Na}$ but decreased proline and $\mathrm{Na}$ contents in sweet pepper leaves. It could be showed from the data that each applied antioxidant completely counteracted the harmful effect of salinity stress levels by increasing $\mathrm{K}$ content and $\mathrm{K} / \mathrm{Na}$ ratio in leaves of sweet pepper plants. The highest increment values of $\mathrm{K}$ content were noticed by Selenium treatment which estimated by 43.62 and $30.74 \%$ in the first and second season, respectively, compared to control treatment meanwhile, Selenium coupled with Glutathione treatment was the most effective in the third season with increment $\mathrm{K}$ value by $62.78 \%$ compared to control treatment. The positive effects of selenium on potassium accumulation were also observed by Pazurkiewicz-Kocot et al. (2003), who found that the content of potassium in maize leaves significantly increased when introducing $10 \mu \mathrm{mol} \mathrm{Se}$ into the medium. Similarly, Kopsell et al. (2000) revealed that potassium levels in cabbage leaves were linearly increased along with the increase in selenium spray concentration in the medium treatment. On the other hand the study of Hawrylak-Nowak et al. (2019) demonstrated that the application of selenium to the medium containing $40 \mathrm{mM} \mathrm{NaCl}$ reduced the level of free proline, relative to the plants growing at moderate salinity levels. 
Table 8. K, Na, K/Na and proline content in leaves of sweet pepper plants grown under salt stress as affected by Glutathione, Selenium and Humic acid treatments during 2018 and 2019 seasons

\begin{tabular}{|c|c|c|c|c|c|c|c|c|c|}
\hline \multicolumn{2}{|c|}{ Growth } & \multicolumn{4}{|c|}{ Season $(2018)$} & \multicolumn{4}{|c|}{ Season (2019) } \\
\hline Factors & Growth & K \% & $\mathrm{Na} \%$ & $\begin{array}{l}\mathrm{K} / \mathrm{Na} \\
\text { ratio }\end{array}$ & $\begin{array}{c}\text { Proline } \\
\%\end{array}$ & K \% & $\mathrm{Na} \%$ & $\begin{array}{l}\mathrm{K} / \mathrm{Na} \\
\text { ratio }\end{array}$ & $\begin{array}{c}\text { Proline } \\
\%\end{array}$ \\
\hline \multirow{5}{*}{ 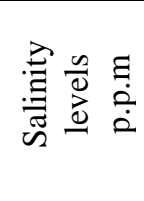 } & Control & $3.42 \mathrm{~A}$ & $0.33 \mathrm{C}$ & $10.30 \mathrm{~A}$ & $0.45 \mathrm{C}$ & $3.49 \mathrm{~A}$ & $0.30 \mathrm{D}$ & $11.60 \mathrm{~A}$ & $0.43 \mathrm{C}$ \\
\hline & 500 & $3.33 \mathrm{~A}$ & $0.38 \mathrm{C}$ & 8.78 B & $0.52 \mathrm{C}$ & $3.35 \mathrm{~B}$ & $0.42 \mathrm{C}$ & $8.18 \mathrm{~B}$ & $0.53 \mathrm{~B}$ \\
\hline & 1000 & $3.17 \mathrm{~B}$ & $0.65 \mathrm{~B}$ & $5.22 \mathrm{C}$ & $0.74 \mathrm{~B}$ & $3.07 \mathrm{C}$ & $0.80 \mathrm{~B}$ & $3.99 \mathrm{C}$ & $0.60 \mathrm{~B}$ \\
\hline & 1500 & $2.86 \mathrm{C}$ & $2.23 \mathrm{~A}$ & $2.21 \mathrm{D}$ & $1.14 \mathrm{~A}$ & $2.84 \mathrm{D}$ & $1.86 \mathrm{~A}$ & $1.84 \mathrm{D}$ & $0.85 \mathrm{~A}$ \\
\hline & Control & $2.59 \mathrm{D}$ & $1.76 \mathrm{~A}$ & $1.47 \mathrm{D}$ & $0.80 \mathrm{~A}$ & $2.83 \mathrm{C}$ & $0.87 \mathrm{~A}$ & $0.60 \mathrm{D}$ & $0.69 \mathrm{~A}$ \\
\hline \multirow{3}{*}{ 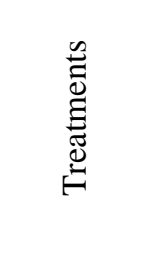 } & $\begin{array}{l}\text { Glutathione } \\
(25 \mathrm{Mg} / \mathrm{L})\end{array}$ & $3.48 \mathrm{~B}$ & $0.73 \mathrm{~B}$ & $4.76 \mathrm{~B}$ & $0.72 \mathrm{~B}$ & $3.25 \mathrm{~B}$ & $0.63 \mathrm{~B}$ & $0.93 \mathrm{~B}$ & $0.59 \mathrm{~B}$ \\
\hline & $\begin{array}{l}\text { Selenium } \\
(5 \mathrm{mg} / \mathrm{L})\end{array}$ & $3.72 \mathrm{~A}$ & $0.50 \mathrm{D}$ & $7.44 \mathrm{~A}$ & $0.61 \mathrm{C}$ & $3.7 \mathrm{~A}$ & $0.61 \mathrm{~B}$ & $1.12 \mathrm{~A}$ & $0.50 \mathrm{C}$ \\
\hline & $\begin{array}{l}\text { Humic acid } \\
(200 \mathrm{mg} / \mathrm{L})\end{array}$ & $2.77 \mathrm{C}$ & $0.60 \mathrm{C}$ & $4.46 \mathrm{C}$ & $0.72 \mathrm{~B}$ & $2.97 \mathrm{C}$ & $0.83 \mathrm{~A}$ & $0.73 \mathrm{C}$ & $0.64 \mathrm{AB}$ \\
\hline
\end{tabular}

*The mean values with the same alphabetical letters do not significantly differ at $0.05 \%$ probability level.

Table 9. K, Na, K/Na and proline content in leaves of sweet pepper plants grown under salt stress as affected by glutathione \&selenium, selenium \& humic acid and glutathione \& humic acid treatments during 2020 season

\begin{tabular}{cccccc}
\hline & & & & Season (2020) \\
\hline \multirow{2}{*}{ Factors } & Growth & K \% & Na \% & K/Na ratio & Proline \% \\
\hline \multirow{3}{*}{ Salinity levels } & Control & $2.92 \mathrm{~A}$ & $0.26 \mathrm{D}$ & $11.23 \mathrm{~A}$ & $0.35 \mathrm{C}$ \\
p.p.m & 500 & $2.76 \mathrm{~B}$ & $0.38 \mathrm{C}$ & $7.26 \mathrm{~B}$ & $0.41 \mathrm{C}$ \\
& 1000 & $2.63 \mathrm{C}$ & $0.92 \mathrm{~B}$ & $3.04 \mathrm{C}$ & $0.75 \mathrm{~B}$ \\
& 1500 & $2.25 \mathrm{D}$ & $1.45 \mathrm{~A}$ & $1.55 \mathrm{D}$ & $1.17 \mathrm{~A}$ \\
Treatments & Control & $2.23 \mathrm{D}$ & $1.05 \mathrm{~A}$ & $2.11 \mathrm{D}$ & $0.80 \mathrm{~A}$ \\
& glutathione \&selenium & $3.63 \mathrm{~A}$ & $0.78 \mathrm{C}$ & $4.65 \mathrm{~A}$ & $0.46 \mathrm{C}$ \\
& selenium \& humic acid & $2.70 \mathrm{~B}$ & $0.81 \mathrm{~B}$ & $3.3 \mathrm{~B}$ & $0.64 \mathrm{~B}$ \\
& glutathione \& humic acid & $2.57 \mathrm{C}$ & $0.86 \mathrm{~B}$ & $2.98 \mathrm{C}$ & $0.78 \mathrm{~A}$ \\
\hline
\end{tabular}

*The mean values with the same alphabetical letters do not significantly differ at $0.05 \%$ probability level.

\section{Effect of the interaction:}

The interaction effects between salinity levels and ameliorative treatments (Figures 22-33) showed that application of the ameliorative treatments either singly in the first and second seasons or in coupled in the third season, significantly increased potassium concentration and subsequent increase in $\mathrm{K} / \mathrm{Na}$ ratio. $\mathrm{K}$ increments estimated by 34.71 and $37.75 \%$ in the first and second seasons respectively, when compared to those plants grown under the same salinity level without protection treatment. Meanwhile, in the third season the coupled treatment of selenium and Glutathione under the highest salinity level achieved the highest increment value for $\mathrm{K}$ estimated by $44.39 \%$ compared to corresponding control. Such Se effect on increasing K uptake and/or $\mathrm{K} / \mathrm{Na}$ ratio and decreasing $\mathrm{Na}^{+}$uptake has been revealed by (Kong et al.2005) who reported that the Selenium application to the salt-stressed Sorrel plants induced the accumulation of $\mathrm{K}$ in leaves and they found that the growth-promoting effect of Se under salinity conditions can be related to the improvement of the $\mathrm{K} / \mathrm{Na}$ ratio. On the other hand, Ibrahim et al. (2017) found that the application of exogenous GSH was more effective in reducing $\mathrm{Na}$ contents, $\mathrm{Na} / \mathrm{K}$ ratio, and mitigating the effects of salt stress on the growth of cotton plants. 


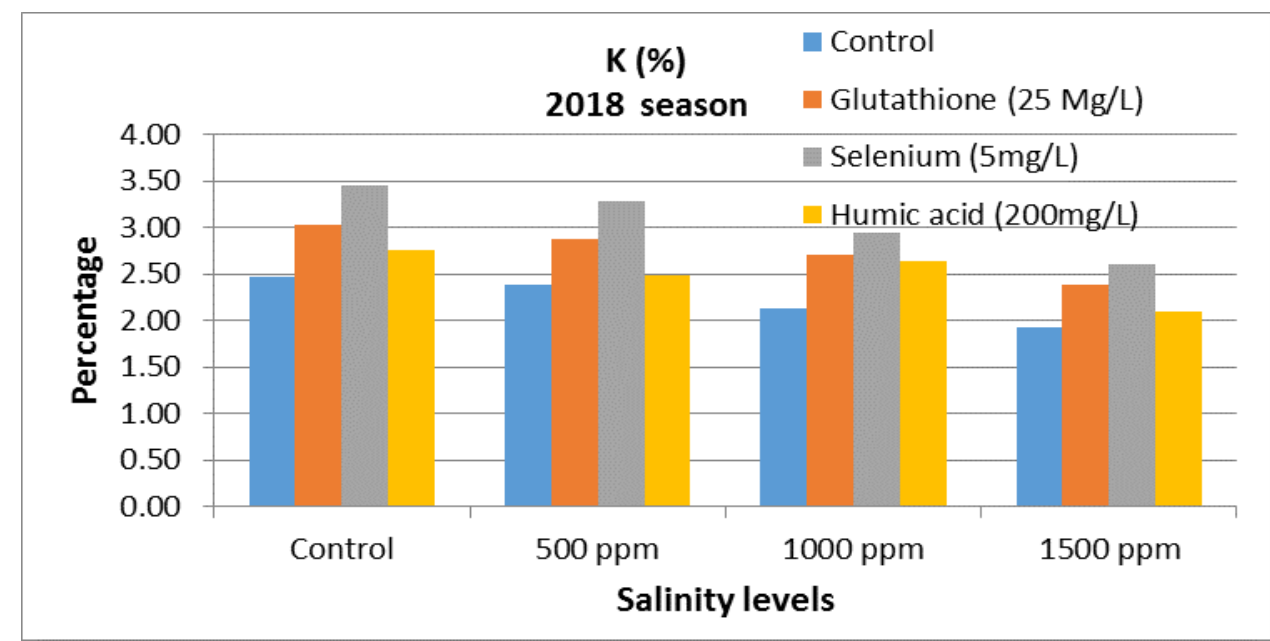

Fig. 22. Potassium accumulation in sweet pepper leaves under different salinity levels in response to Glutathione, Selenium and Humic acid treatments during 2018 season

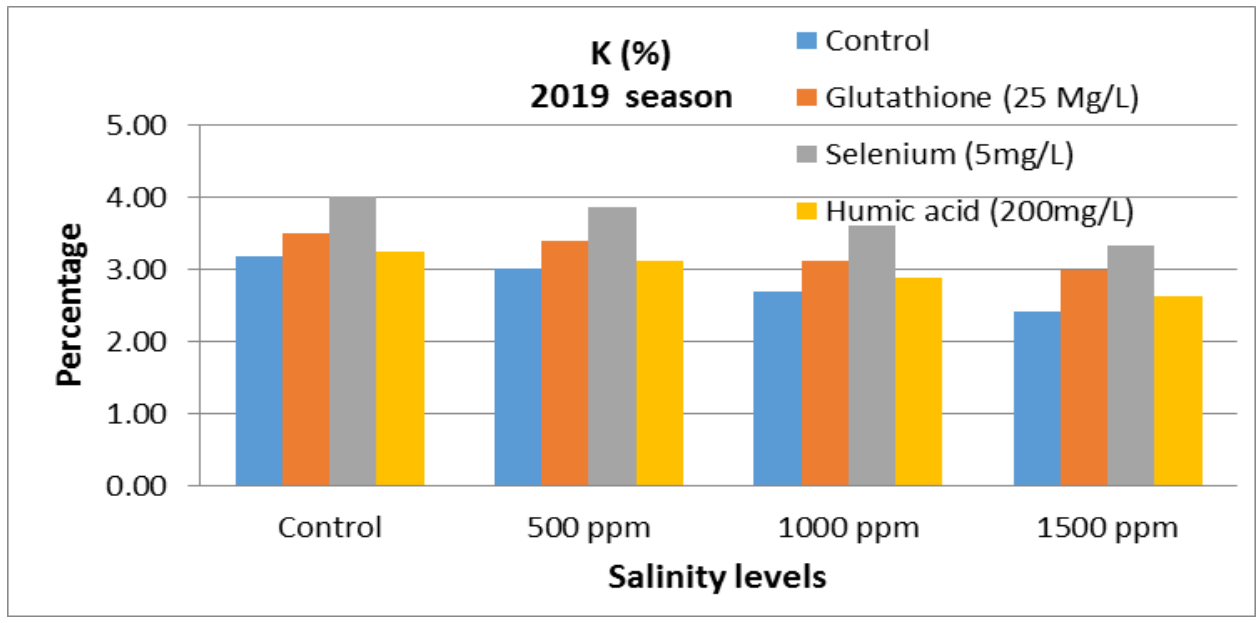

Fig. 23. Potassium accumulation in sweet pepper leaves under different salinity levels in response to Glutathione, Selenium and Humic acid treatments during 2019 season

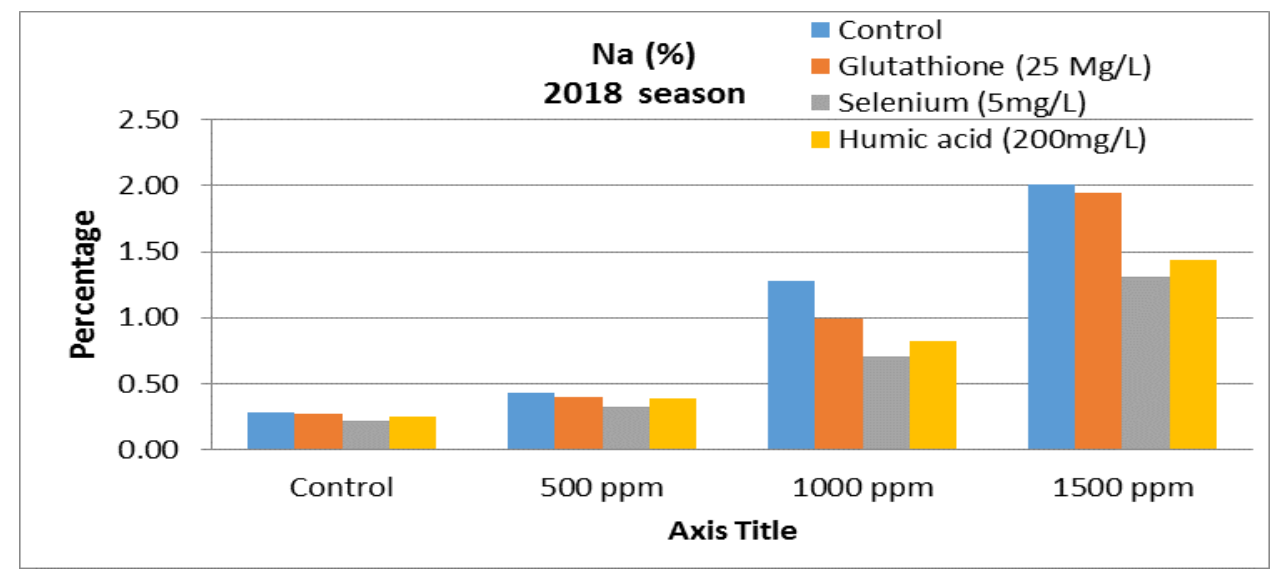

Fig. 24. Sodium accumulation in sweet pepper leaves under different salinity levels in response to Glutathione, Selenium and Humic acid treatments during 2018 season 


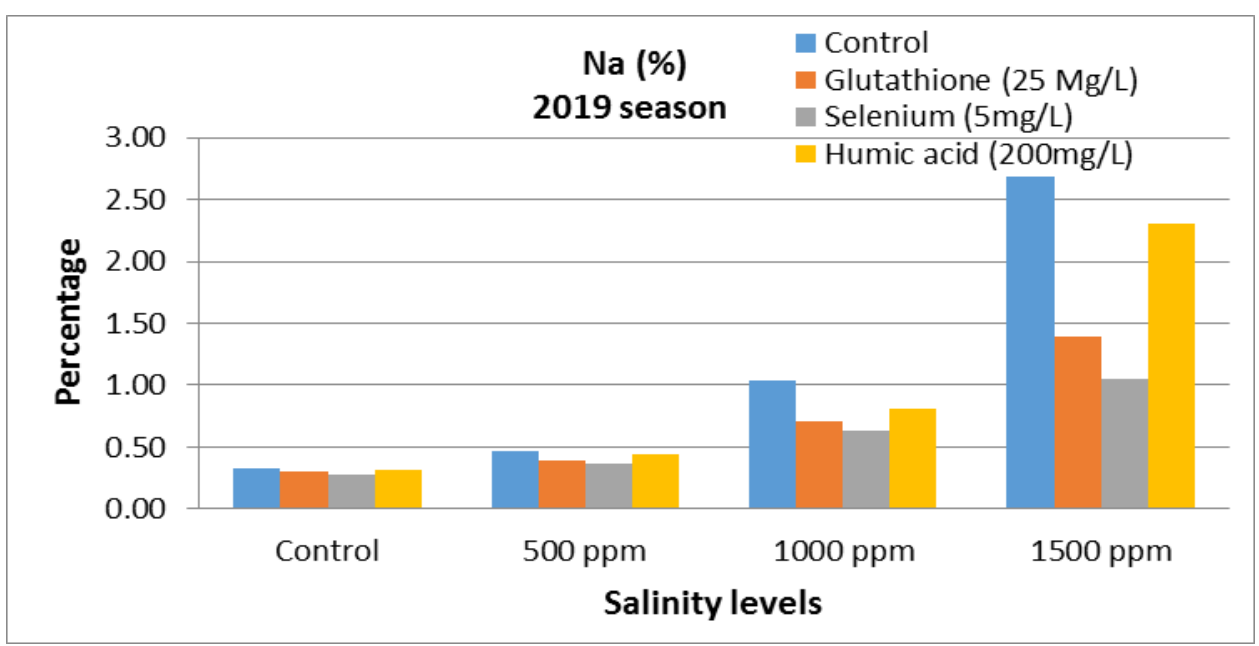

Fig. 25. Sodium accumulation in sweet pepper leaves under different salinity levels in response to Glutathione, Selenium and Humic acid treatments during 2019 season

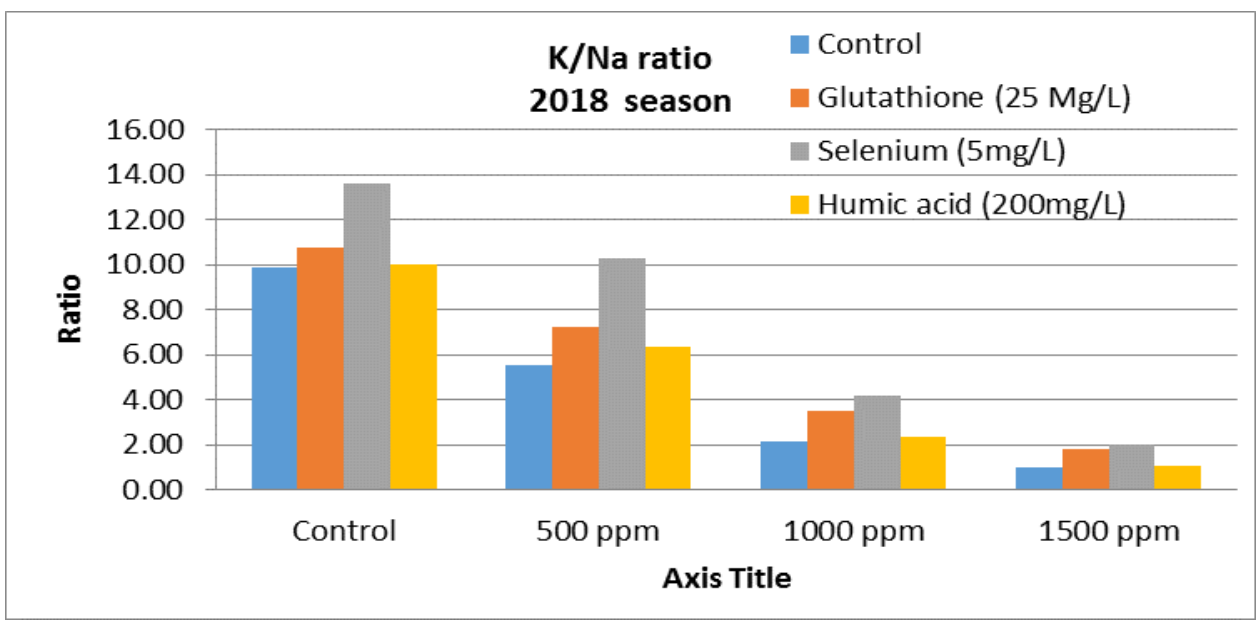

Fig. 26. K/Na ratio in sweet pepper leaves under different salinity levels response to Glutathione, Selenium and Humic acid treatments during 2018 season

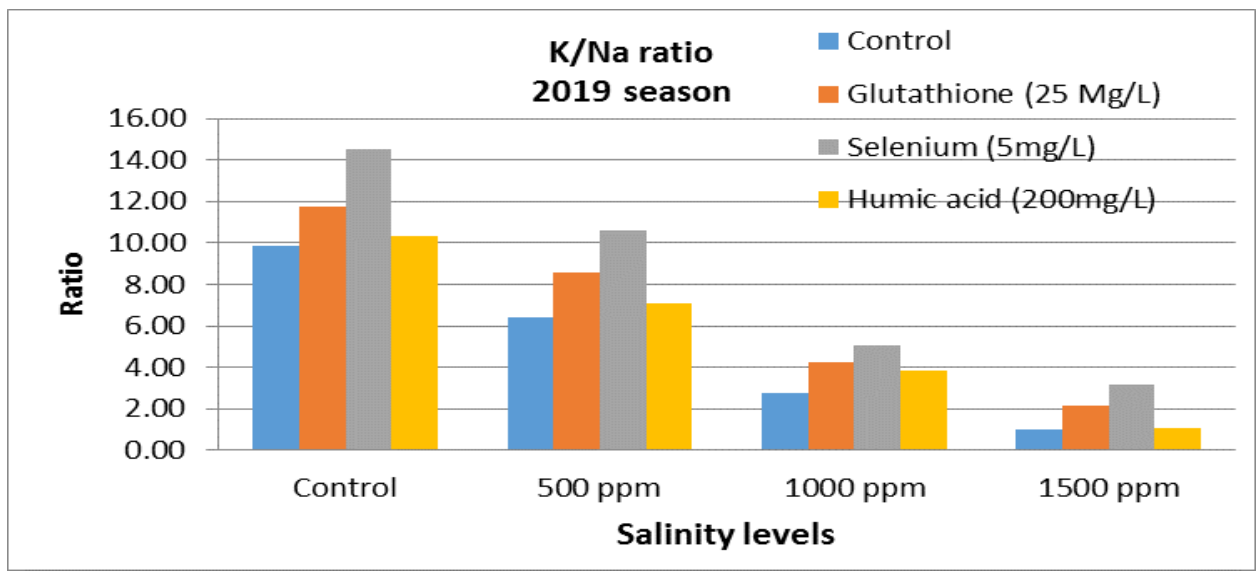

Fig. 27. K/Na ratio in sweet pepper leaves under different salinity levels in response to Glutathione, Selenium and Humic acid treatments during 2019 season 


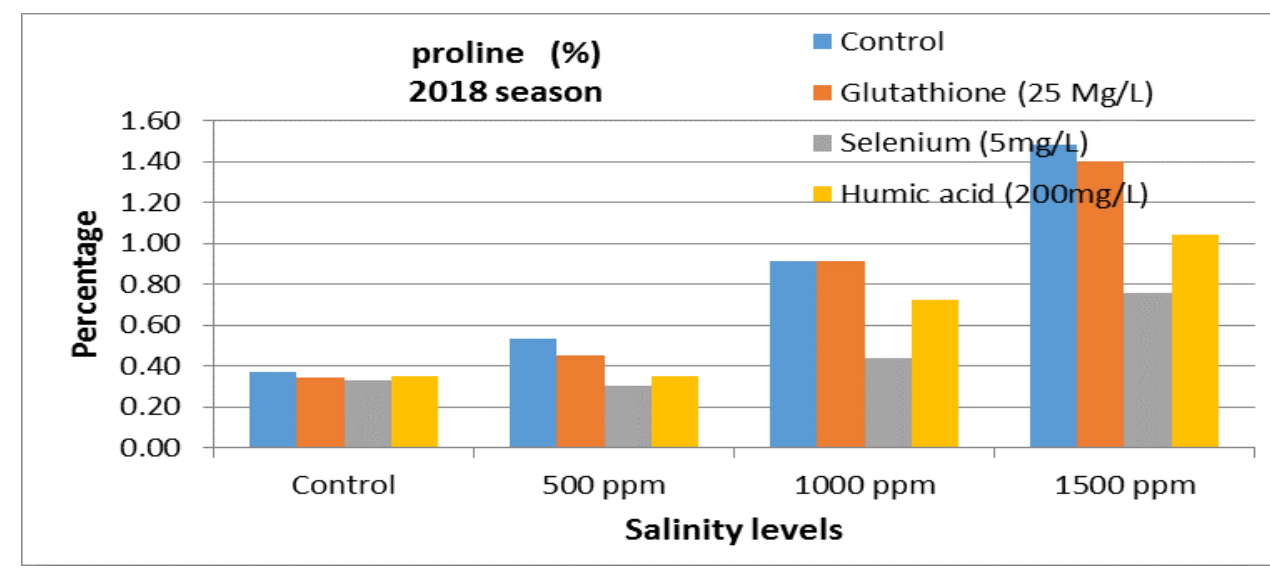

Fig. 28. Proline accumulation in sweet pepper leaves under different salinity levels in response to Glutathione, Selenium and Humic acid treatments during 2018 season

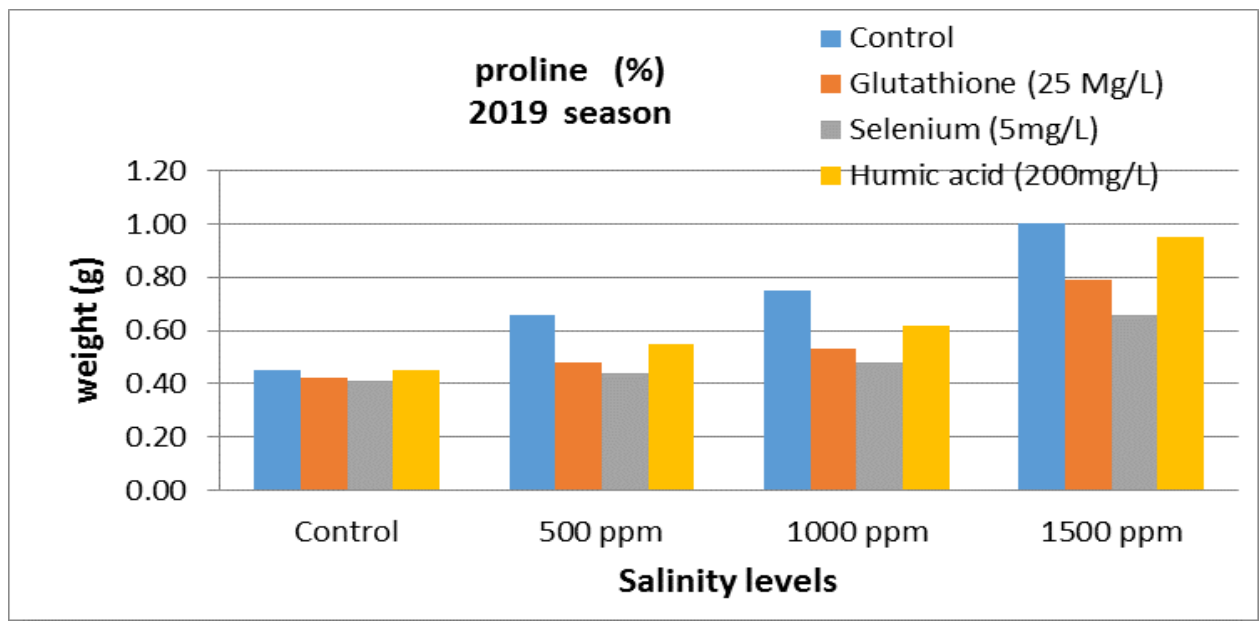

Fig. 29. Proline accumulation in sweet pepper leaves under different salinity levels in response to Glutathione, Selenium and Humic acid treatments during 2019 season

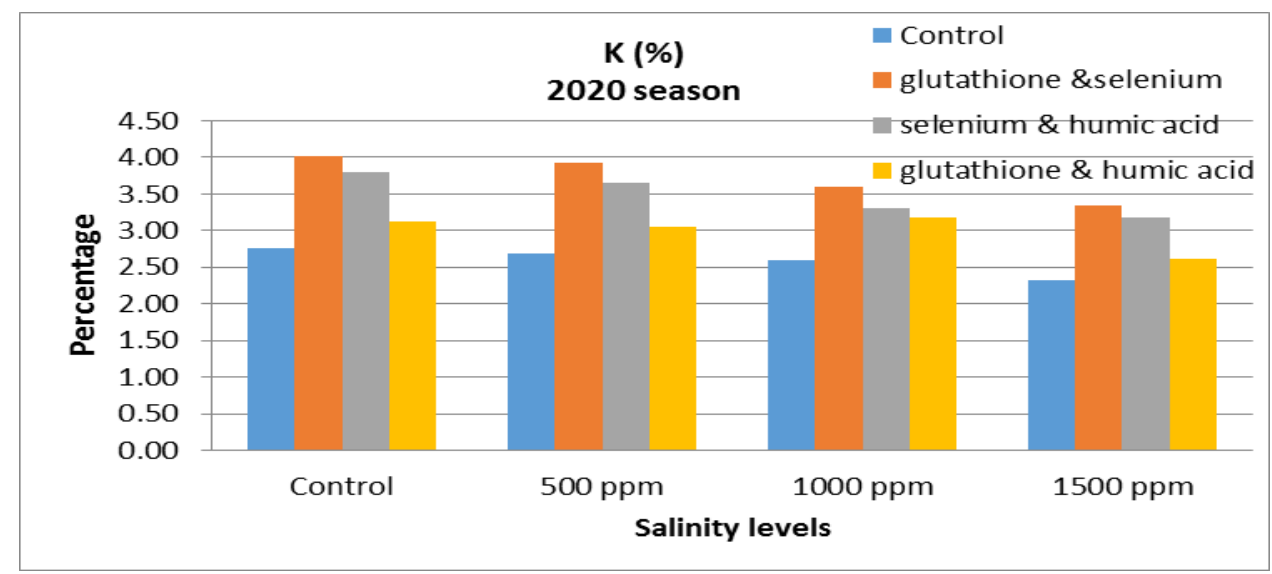

Fig. 30. Potassium accumulation in sweet pepper leaves under different salinity levels in response to Glutathione\& Selenium, Selenium\& Humic acid and Glutathione\& Humic acid treatments during 2020 season 


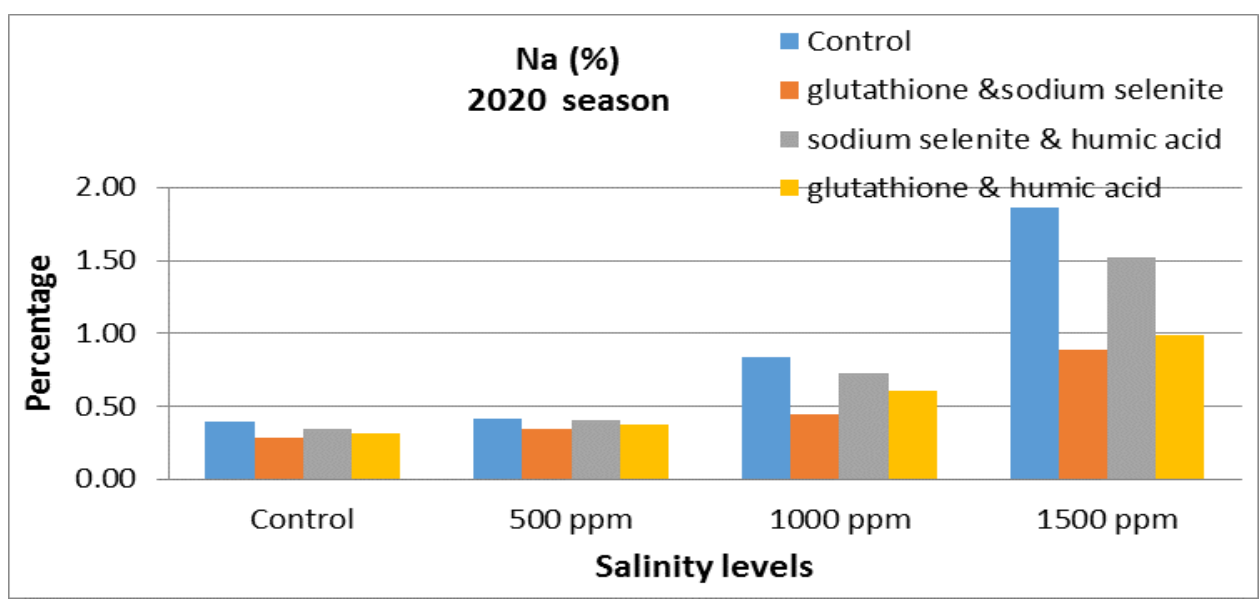

Fig .31. Sodium accumulation in sweet pepper leaves under different salinity levels in response to Glutathione\& Selenium, Selenium\& Humic acid and Glutathione\& Humic acid treatments during 2020 season

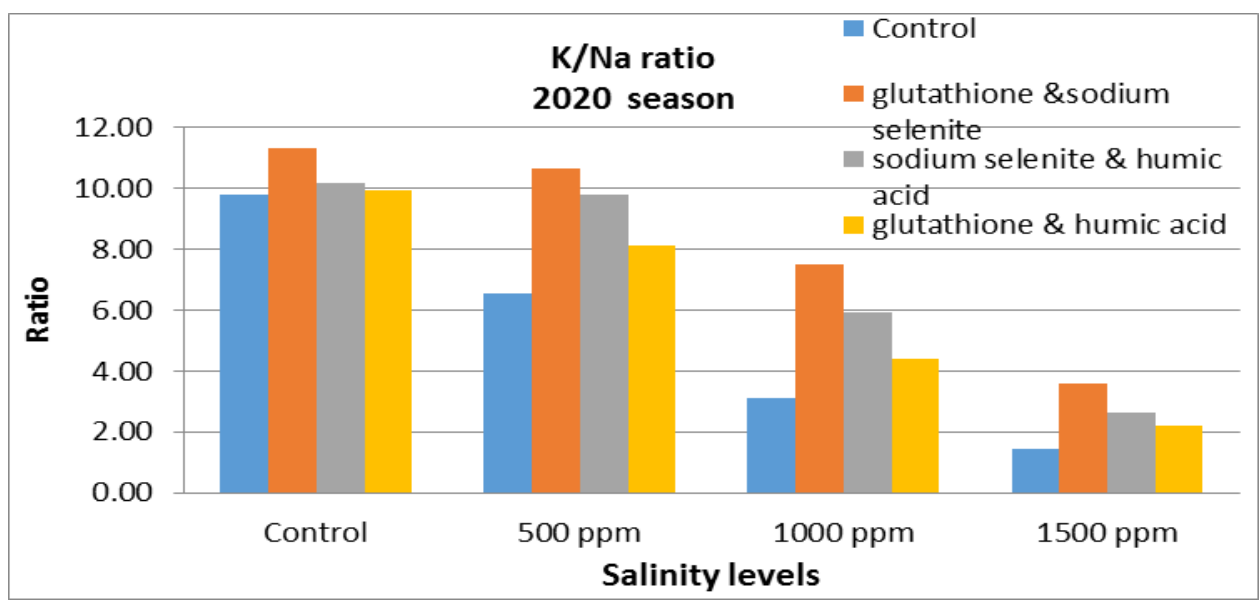

Fig. 32. K/Na ratio in sweet pepper leaves under different salinity levels in response to Glutathione\& Selenium, Selenium \& Humic acid and Glutathione\& Humic acid treatments during 2020 season

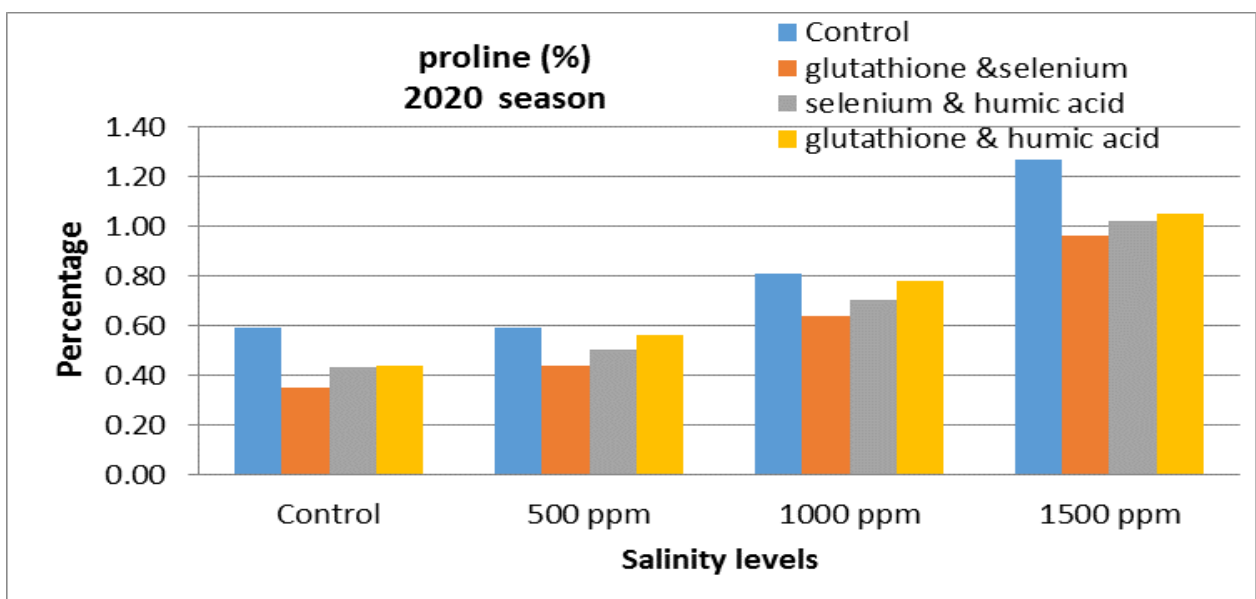

Fig. 33. Proline accumulation in sweet pepper leaves under different salinity levels in response to Glutathione\& Selenium, Selenium\& Humic acid and Glutathione\& Humic acid treatments during 2020 season 


\section{Sweet pepper yield}

\section{Effect of salinity:}

Tables 10 and11 illustrate that Irrigation of sweet pepper plants with saline water at all salinity levels significantly inhibited fruit yield plant $^{-1}$ and it was more severely at the highest salinity level. The maximum reduction in yield was recorded at $1500 \mathrm{ppm} \mathrm{NaCl}$ in the three seasons and this reductions of fruits yield plant ${ }^{-1}$ were estimated by $46.36,53.05$ and $40.54 \%$ in the first, second, and third seasons respectively compared to the non-treated plants, The negative effect of salinity on sweet pepper yield may be due to its inhibitory effect on the uptake and translocation of some major and micro elements within plant roots (Larcher, 1980). Also, Mozafariyan et al. (2013) reported that the decline in tomato yield derived from salinity stress could be a result from the negative relationship between salinity and photosynthetic rate. Furthermore Navarro et al., (2002) reported that reduced growth and yield of bell pepper due to salinity was attributed to reduced water

content of leaves caused by poor osmotic adjustment. Similar results were reported by Rubio et al. (2010) who recorded lower fruit yield from the saline water treatment $\left(4.6 \mathrm{dS} \mathrm{m}^{-1}\right)$ when compared to control $(2.6 \mathrm{dS}$ $\mathrm{m}^{-1}$ ). Also Savvas et al. (2007) obtained lower fruit yield by irrigation with water of high salinity for greenhouse-grown bell pepper.

Effect of of Glutathione, Selenium and Humic acid treatments:

Tables 10 and 11 showed the influence of different mitigation treatments (Glutathione, Selenium and Humic acid and their coupled treatments) on fruit yield of sweet pepper plants. The statistical comparisons among the mean values of the different ameliorative treatments illustrated that each mitigation treatment used either singly or in coupled was associated significantly with an increase in yield plant $^{-1}$ compared to control of the three seasons of study (Tables 10 and $11)$.

Table 10. Fruit yield plant ${ }^{-1}$ of sweet pepper plants grown under salt stress as affected by Glutathione, Selenium and humic acid treatments during 2018 and 2019 seasons

\begin{tabular}{cccc}
\hline & Growth & Season (2018) & Season (2019) \\
\hline \multirow{2}{*}{ Factors } & fruit yield/plant (g) & fruit yield/plant (g) \\
\hline \multirow{3}{*}{ Salinity levels p.p.m } & Control & $555.10 \mathrm{~A}$ & $466.24 \mathrm{~A}$ \\
& 100 & $539.97 \mathrm{C}$ & $462.34 \mathrm{~A}$ \\
& 1500 & $385.93 \mathrm{~B}$ & $308.49 \mathrm{~B}$ \\
& Control & $297.74 \mathrm{D}$ & $218.92 \mathrm{C}$ \\
Treatments & $396.75 \mathrm{D}$ & $302.67 \mathrm{D}$ \\
& Glutathione $(25 \mathrm{Mg} / \mathrm{L})$ & $461.54 \mathrm{~B}$ & $375.38 \mathrm{~B}$ \\
& Selenium $(5 \mathrm{mg} / \mathrm{L})$ & $493.70 \mathrm{~A}$ & $433.94 \mathrm{~A}$ \\
& Humic acid $(200 \mathrm{mg} / \mathrm{L})$ & $426.75 \mathrm{C}$ & $344.00 \mathrm{C}$ \\
\hline
\end{tabular}

*The mean values with the same alphabetical letters do not significantly differ at $0.05 \%$ probability level.

Table 11. Fruit yield/plant of sweet pepper plants grown under salt stress by glutathione \&selenium, selenium $\&$ humic acid and glutathione $\&$ humic acid treatments during 2020 season

Season (2020)

\begin{tabular}{lcc}
\hline Factors & Characters & fruit yield/plant (g) \\
\hline \multirow{3}{*}{ Salinity levels p.p.m } & Control & $525.24 \mathrm{~A}$ \\
& 500 & $493.18 \mathrm{~B}$ \\
& 1000 & $443.27 \mathrm{C}$ \\
Treatments & 1500 & $312.31 \mathrm{D}$ \\
& Control & $371.87 \mathrm{D}$ \\
& glutathione \&selenium & $541.40 \mathrm{~A}$ \\
& selenium \& humic acid & $467.46 \mathrm{~B}$ \\
glutathione \& humic acid & $393.26 \mathrm{C}$ \\
\hline
\end{tabular}

*The mean values with the same alphabetical letters do not significantly differ at $0.05 \%$ probability level. 
The highest increment of fruit yield plant ${ }^{-1}$ (24.44 and $43.37 \%$ ) in the first and the second seasons respectively, were obtained by Se application. Moreover, in the third season of the study, the coupled treatment of Glutathione and Selenium surpassed those of the other coupled treatments on fruits yield plant $^{-1}$ with the increment value of $45.59 \%$. These results are in agreement with those found by Yassen et al. (2011) who demonstrated that Selenium application to potato plants promoted plant growth, tuber yield over the control treatments.Effect of the interaction:

The comparisons among the means of different interactions of salinity levels and (Glutathione, Selenium and Humic acid treatments) singly or in coupled on fruits yield of sweet pepper plants are shown in Figs. (34-36). The obtained results indicated that fruits yield of sweet pepper plant $^{-1}$ were significantly affected by these interaction treatments in the three seasons. The application of Selenium ${ }^{-1}$ alone in the first two seasons or coupled with Glutathione in the third season under different salinity levels was favorable for the plants to express their best performance. The highest percentage increments of fruit yield plant ${ }^{-1}$ at the highest salinity were in the present of Selenium ${ }^{-1}$ alone in the first and second seasons or coupled with Glutathione level in the third season which estimated by $18.59,29.73$ and $27.84 \%$ respectively. These results are in agreement with Daniel et al. (2015) who reported a positive effect of selenium could be explained on the ground that selenium plays an important role in enhancing their anti-oxidative capacity and thereby improve growth and yield.

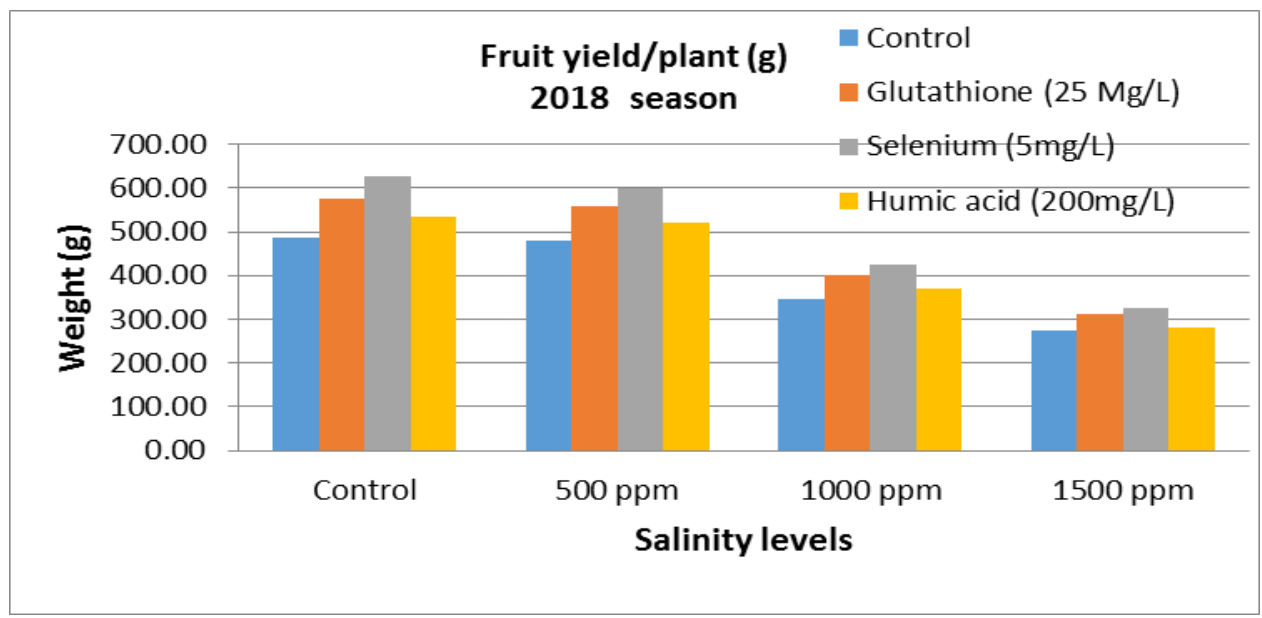

Fig. 34. Fruit yield plant ${ }^{-1}$ of sweet pepper under different salinity levels in response to Glutathione, Selenium and Humic acid treatments during 2018 season

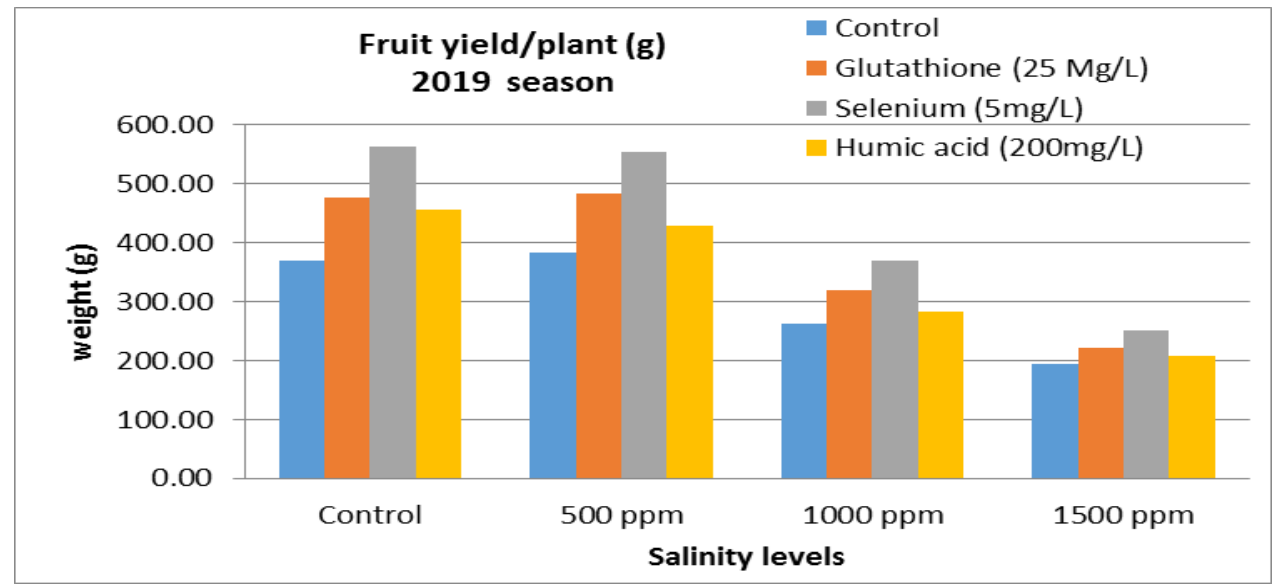

Fig. 35. Fruit yield plant ${ }^{-1}$ of sweet pepper under different salinity levels in response to Glutathione, Selenium and Humic acid treatments during 2019 season 


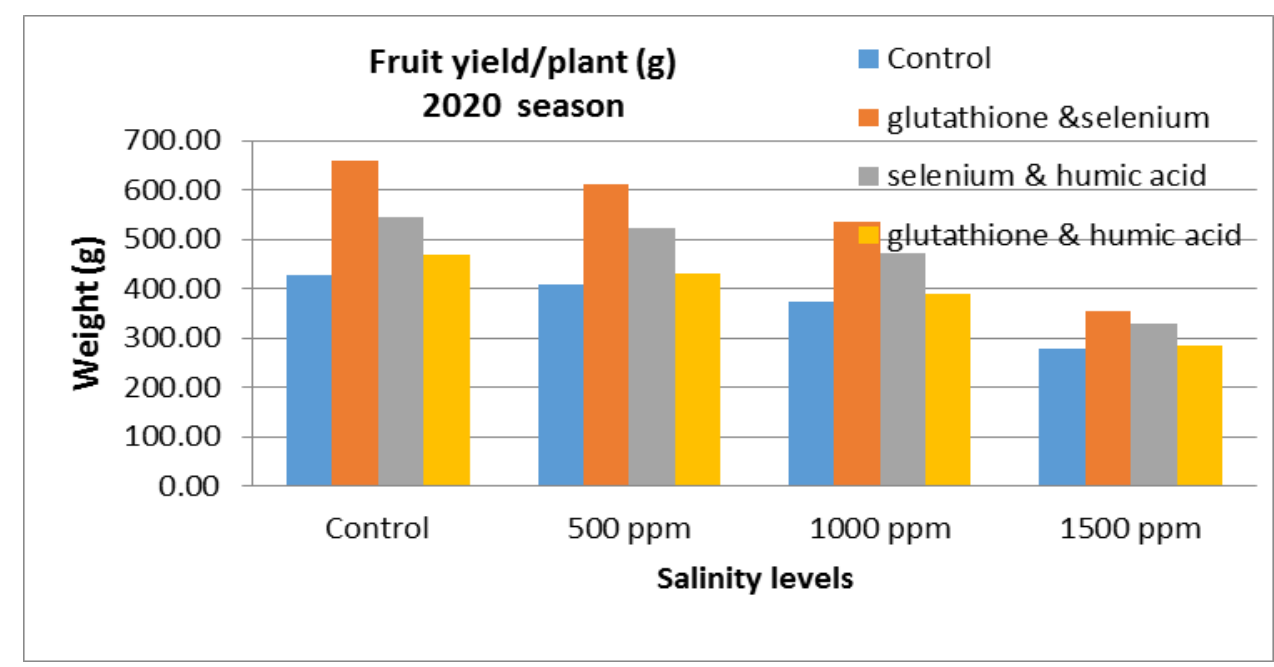

Fig. 36. Fruit yield plant ${ }^{-1}$ of sweet pepper under different salinity levels in response to Glutathione\& Selenium, Selenium\& Humic acid and Glutathione\& Humic acid treatments during 2020 season

Also Ramos et al. (2010) found that the application of Selenium at low concentrations is more appropriate for lettuce bio-fortification because it favors plant growth. A similar trend was reported by Yassen et al. (2011) who demonstrated that selenium foliar application at 20 and $40 \mathrm{~g} / \mathrm{fed}$, promoted plant growth, tuber yield and quality over the control treatments. Moreover, Khattab (2007) found that Glutathione application enhances the chlorophyll biosynthesis or decreases its degradation and integrated into primary metabolism, and it can affect the functioning of the signal transduction pathway by modulating cellular redox state and thus return in increasing crop yield.

\section{CONCLUSIONS}

This study suggests that, the application of either Selenium singly or in coupled with Glutathione regulates sweet pepper response to salt stress and may be used to enhance plant growth and mineral status. Application of Selenium singly or in coupled with Glutathione alleviate salt stress, gave highest growth parameters, increased chlorophyll content, plant leaf area also enhanced its mineral status such as $\mathrm{N}, \mathrm{P}, \mathrm{K}$, and $\mathrm{Ca}$ concentrations and decreased $\mathrm{Na}$ concentrations compared to control (spraying with distilled water). Additionally, an interesting phenomenon was found in our experiment that the application of either Selenium singly or in coupled with Glutathione led to reduction of $\mathrm{Na}+$ and proline concentration and increased $\mathrm{K}+$ concentration in sweet pepper leaves, indicating that selective absorption of $\mathrm{K}^{+}$over $\mathrm{Na}^{+}$(high $\mathrm{K}+/ \mathrm{Na}+$ ) could be one of the mechanism for this plant adapting to salt stress.

\section{REFERENCES}

Abd Elhamid, E. M., M. S.Sadak and M. M. Tawfik. 2018. Glutathione treatment alleviate salinity adverse effects on growth, some biochemical aspects, yield quantity and nutritional value of chickpea plant. Sci Fed J Global Warming. 2(2): 1-11..

Abdelaal, K. A., L. M. EL-Maghraby, H.Elansary, Y. M.Hafez, E. I.Ibrahim, M.El-Banna. and A. Elkelish. 2020. Treatment of sweet pepper with stress toleranceinducing compounds alleviates salinity stress oxidative damage by mediating the physio-biochemical activities and antioxidant systems. Agronomy. 10(1): 26.

Abul-Soud, M. A. and S. H. Abd-Elrahman. 2016. Foliar selenium application to improve the tolerance of eggplant grown under salt stress conditions. Int. J. Plant Soil Sci. 9: $1-10$.

Alsina, I., L. Dubova, Z. Smiltina, L. Stroksa and M. Duma. 2012. The effect of selenium in yield quality of lettuce. Acta Horticulture. 939: 269-275.

Astaneh, R. K., S.Bolandnazar, F. Z.Nahandi and S. Oustan. 2019. Effects of selenium on enzymatic changes and productivity of garlic under salinity stress. South African J. Botany. 121: 447-455.

Babu, M. A., D.Singh and K. M. Gothandam. 2012. The effect of salinity on growth, hormones and mineral elements in leaf and fruit of tomato cultivar PKM1. J Anim Plant Sci. 22(1), 159-164.

Bates, L. S., R. P.Waldren and I. D. Teare. 1973. Rapid determination of free proline for water-stress studies. Plant soil. 39(1): 205-207.

Boghdady, M. S., E.Desoky, S. N.Azoz and D. M.Abdelaziz. 2017. Effect of selenium on growth, physiological aspects and productivity of faba bean (Vicia faba L.). EgyptJ. Agron.. 39(1): 83-97. 
Calvo, P., L.Nelson and J. W. Kloepper. 2014. Agricultural uses of plant biostimulants. Plant soil. 383(1): 3-41.

Canellas, L. P., F. L.Olivares, N. O. Aguiar, D. L.Jones, A.Nebbioso, P.Mazzei and A.Piccolo. 2015. Humic and fulvic acids as biostimulants in horticulture. Scientia horticulturae. 196: 15-27.

Cartes, P., L.Gianfreda and M. L. Mora. 2005. Uptake of selenium and its antioxidant activity in ryegrass when applied as selenate and selenite forms. Plant Soil. 276(1): 359-367.

Chapman, H. D. and P. F. Pratt. 1962. Methods of analysis for soils, plants and waters. Soil Sci. 93(1): 68.

Chartzoulakis, K. and G.Klapaki. 2000. Response of two greenhouse pepper hybrids to $\mathrm{NaCl}$ salinity during different growth stages. Scientia horticulture. 86(3): 247260.

Chen, J. H., H. W.Jiang, E. J. Hsieh, H. Y.Chen, C. T.Chien, H. L.Hsieh and T. P. Lin. 2012. Drought and salt stress tolerance of an Arabidopsis glutathione S-transferase U17 knockout mutant are attributed to the combined effect of glutathione and abscisic acid. Plant Physiology. 158(1): 340-351.

Clapp, C. E., R. S.Vial, Y.Chen, A. J.Palazzo, V. W. Cline and J. M. Baker. 2002. Stimulation of plant growth by humic substances ASA-CSSASSSA Annual Meeting Abstracts. Paper No. S03-clapp.

Co Stat Program. 2008. Disclaimer and License for CoStat 6.4. Cohort Software Inc., Monterey, CA, USA.

Daniel, N., G.Subramaniyan, K.Chimannan and I. A. Padikasan. 2015. Antiokxidant profiling of seleium fortified tomato (Solanum lycopersicum). International Research J. Of Pharmacy. 6: 299-304.

Debouba, M., H. Gouia, A. Suzuki, M.H. Ghorbel. 2006. NaCl stress effects on enzymes involved in nitrogen assimilation pathway in tomato "Lycopersicon esculentum" seedlings. J Plant Physiol.163:1247-1258.

Diao, M., L.Ma, J.Wang, J.Cui, A.Fu and H. Y. Liu. 2014. Selenium promotes the growth and photosynthesis of tomato seedlings under salt stress by enhancing chloroplast antioxidant defense system. J. of Plant Growth Regulation. 33(3): 671-682.

Duma, M., I. Alsina, L. Dubova, L. Stroksa and Z. Smiltina. 2011. The effect of sodium selenite and selenite on the quality of lettuce. foodbalt. Fundamental library FAO. 3944.

El-Fouly, M. M., Z. M.Moubarak and Z. A. Salama. 2000. Micronutrients foliar application increases salt tolerance of tomato seedlings. In International Symposium on Techniques to Control Salination for Horticultural Productivity. 573: 467-474.

Elkhatib, H. A., E. A.Elkhatib, A. M.Khalaf Allah and A. M. El-Sharkawy. 2004. Yield response of salt-stressed potato to potassium fertilization: A preliminary mathematical model. J. Plant Nutrition. 27(1):111-122.

FAOSTAT, F. 2018. Disponível em: http://www. fao. org/faostat/en/\# home. Acesso em. 30.
Faried, H.N., C.M.Ayyub, M.Amjad and R. Ahmed. 2016. Salinity impairs ionic, physiological and biochemical attributes in potato. Pakistan j. of agricultural sci. 53 (1): 17-25.

Fayed, A. M. 1997. Evolution of some cultivars and mutants of cow pea (Vigna unguiculata L.) under Kafr EL Sheikh condition M. Sc (Doctoral dissertation, Thesis. Fac. Agric, Kafr EL-Sheikh, Tanta. University).

Feng, R., C.Wei and S.Tu. 2013. The roles of selenium in protecting plants against abiotic stresses. Environ Experim Bot. 87:58-68.

Filek, M., R.Keskinen, H.Hartikainen, I.Szarejko, A.Janiak, Z.Miszalski and A. Golda. 2008. The protective role of selenium in rape seedlings subjected to cadmium stress. Jo. Plant Physiol. 165(8):833-844.

Foyer, C. H. and G. Noctor. 2005. Oxidant and antioxidant signalling in plants: a re-evaluation of the concept of oxidative stress in a physiological context. Plant, Cell\& Environ. 28(8):1056-1071.

Franken, M., F. G. Lima, L. Baracioli, J. Nicolau. 2014. Effect of short term salt stress on chlorophyll content, protein and activities of catalase and ascorbate peroxidase enzymes in pearl millet. American J. of Plant Physiology. 9(1): A1422.

Gemin, L. G., Á. F.Mógor, J. D. O.Amatussi and G. Mógor. 2019. Microalgae associated to humic acid as a novel biostimulant improving onion growth and yield. Scientia Hort. 256:108560.

Ghasemi, Y., G. H. Kamran, P. Hemattollah and A. S. Roqieh. 2016. Effect of selenium enrichment on the growth, photosynthesis and mineral nutrition of broccoli. Not Sci. Biol. 8 (2): 199-203.

Ghoname, A. A., M. G.Dawood, M. S.,Sadak and A. A. Hegazi. 2010. Improving nutritional quality of hot pepper (Capsicum annuum L.) plant via foliar application with arginine or tryptophan or glutathione. J. Biol Chem Environ. Sci. 5:409-429.

Ghosh, S. C., K. Asanuma, A. Kusutani and M. Toyota. 2001. Effect of Salt Stress on Some Chemical Components and Yield of Potato. Soil Sci. Plant Nutr. 47 (3): 467-475.

Gul, H., S.Kinza, Z. K.Shinwari and M. Hamayun. 2017. Effect of selenium on the biochemistry of Zea mays under salt stress. Pak. J. Bot. 49(SI), 25-32.

Hasanuzzaman, M., M. A.Hossain, J. A. T.da Silva and M. Fujita. 2012. Plant response and tolerance to abiotic oxidative stress: antioxidant defense is a key factor. In Crop stress and its management: perspectives and strategies (pp. 261-315). Springer, Dordrecht.

Hasanuzzaman, M., K. Nahar and M. Fujita. 2013. Plant response to salt stress and role of exogenous protectants to mitigate salt-induced damages. Ecophysiology and responses of plants under salt stress, Springer, New York. 25-87.

Hasegawa, P. M., R. A.,Bressan, J. K.Zhu and H. J. Bohnert. 2000. Plant cellular and molecular responses to high salinity. Annual Review Plant Biology. 51(1):463-499. 
Hawrylak-Nowak, B. 2008. Effect of selenium on selected macronutrients in maize plants. J. Elementol. 13(4): 513519.

Hawrylak-Nowak, B., K.Rubinowska, J.Molas, W.Woch, R. Matraszek-Gawron and A. Szczurowska. 2019. Seleniuminduced improvements in the ornamental value and salt stress resistance of Plectranthus scutellarioides (L.) R. Br. Folia Horticulturae. 31(1):213-221.

Hemmat, K. 2007. Role of Glutathione and polyadenylic acid on the oxidative defense systems of two different cultivars of canola seedlings grown under saline condition. Aust. J.Basic and App.1 Sci. 1(3): 323-333.

Horneck, D. A. and D.Hanson. 1998. Determination of potassium and sodium by flame emission spectrophotometry. Handbook of reference methods for plant analysis. 19:153-155.

$\mathrm{Hu}$, Y. and U. Schmidhalter. 2005. Drought and salinity: a comparison of their effects on mineral nutrition of plants. J. Plant Nutr. \& Soil Sci. 168: 541-549.

Ibrahim, W., I. M. Ahmed, X.Chen and F. Wu. 2017. Genotype-dependent alleviation effects of exogenous GSH on salinity stress in cotton is related to improvement in chlorophyll content, photosynthetic performance, and leaf/root ultrastructure. Environmental Sci. and Pollution. 24(10):9417-9427.

Jackson, M. L. 1973. Soil Chemical A. Prentice. Hall of India Private Limited, New Delhi. 498.

Jimenez-Garcia, S. N., M. A.Vázquez-Cruz, L. Garcia-Mier, R.G. Guevara-Gonzalez, I. Torres-Pacheco, R.V. OcampoVelazquez, A. Cruz-Hernandez, A.A. Feregrino-Perez. 2014. Changes in the quantity of phenolic compounds in peppers (Capsicum annuum L.) sprinkled with elicitors under cold stress. J Chem Biol Phys Sci. 4(5):11-17

Kaur, N., S.Sharma, S.Kaur and H.Nayyar. 2014. Selenium in agriculture: a nutrient or contaminant for crops?. Archives of Agronomy and Soil Sci. 60(12) :1593-1624.

Khattab, H. 2007. Role of glutathione and polyadenylic acid on the oxidative defense systems of two different cultivars of canola seedlings grown under saline conditions. Australian J. Basic Applied Sci. 1(3):323-334.

Kong, L., M.Wang and D. Bi. 2005. Selenium modulates the activities of antioxidant enzymes, osmotic homeostasis and promotes the growth of sorrel seedlings under salt stress. Plant Growth Regulation. 45(2): 155-163.

Kopsell, D. A., W. M. Randle and H. A. Mills. 2000. Nutrient accumulation in leaf tissue of rapid cycling Brassica oleracea responds to increasing sodium selenate concentrations'. Plant Nutr. 23(7): 927-935.

Larcher, W. 1980. Physiological Plant Ecology. 2nd edition. SpringerVerlag.

Lee, S.K.D. 2006. Hot pepper response to interactive effects of salinity and boron. Plant Soil Environment. 52: 227233.

Mackowiak, C. L., P. R., Grossl and B. G. Bugbee. 2001. Beneficial effects of humic acid on micronutrient availability to wheat. Soil Sci. Soci. A. J. 65(6):17441750 .
Mozafariyan, M., K.Saghafi, A. E.Bayat and S. Bakhtiari. 2013. The effects of different sodium Chloride concentrations on the growth and photosynthesis parameters of tomato (Lycopersicum esculentum cv. Foria). International J. of Agriculture and Crop Sci. 6(4):203.

Munns, R. and M.Tester. 2008. Mechanisms of salinity tolerance. Annu. Rev. Plant Biol. 59: 651-681.

Nahar, K., M.Hasanuzzaman, M. M.Alam and M. Fujita. 2015. Roles of exogenous glutathione in antioxidant defense system and methylglyoxal detoxification during salt stress in mung bean. Biologia Plantarum. 59(4), 745756.

Nardi, S., P.Carletti, D.Pizzeghello and and A. Muscolo. 2009. Biological activities of humic substances. Biophysico-chemical processes involving natural nonliving organic matter in environmental systems. 2(1):305-339.

Navarro, J. M., C.Garrido, M.Carvajal and V.Martinez. 2002. Yield and fruit quality of pepper plants under sulphate and chloride salinity. The J. of Horticultural Sci. and Biotechnology. 77(1):52-57.

Neri, D., E. M.Lodolini, G.Savini, P.Sabbatini, G.Bonanomi and F. Zucconi. 2002. Foliar application of humic acids on strawberry (cv Onda). Acta horticulturae. 297-302.

Noctor, G., A. Mhamdi, S. Chaouch, Y. Han, J. Neukermans, B. Marquez-Garcia, G. Queval, C.H. Foyer. 2012. Glutathione in plants: an integrated overview. Plant Cell Environ. 35(2):454-484.

Page, A., R. Miller and D. Keeneny. 1982. Methods of soil analysis. Part 2. chemical and microbiological properties. 2nd edition. Agron. Madison, Wisconsin, USA.

Pazurkiewicz-Kocot, K., W. galas and A. kita. 2003. The effect of selenium on the accumulation of some metals in zea mays. Cell. Mol. Biol. Lett. 8(1): 97-103.

Pennanen, A., T. XUe and H. Hartikainen. 2002. Protective role of selenium in plant subjected to severe UV irradiation stress. J. Applied Botany (1995).76(1-2):66-76.

Qadir, M. and S.Schubert. 2002. Degradation processes and nutrient constraints in sodic soils. Land Degradation \& Development. 13(4):275-294.

Radi, A. A., F. A.Farghaly and A. M. Hamada. 2013. Physiological and biochemical responses of salt-tolerant and salt-sensitive wheat and bean cultivars to salinity. J. Biol. Earth Sci. 3(1): 72-88.

Rahnama, A., R. A.James, K. Poustini and R. Munns. 2010. Stomatal conductance as a screen for osmotic stress tolerance in durum wheat growing in saline soil. Functional Plant Biology. 37(3):255-263.

Ramos, S. J., V.Faquin, L. R. G.Guilherme, E. M. Castro, F. W.Ávila, G. S.Carvalho and C.Oliveira. 2010. Selenium biofortification and antioxidant activity in lettuce plants fed with selenate and selenite. Plant, Soil Environ. 56(12):584-588 
Rogers, M., C. Grieve and M. Shannon. 2003. Plant growth and ion relations in lucerne (Medicago sativa L.) in response to the combined effects of $\mathrm{NaCl}$ and $\mathrm{P}$. Plant Soil. 253:187-194.

Rubio, F., L.Arévalo, F.Caballero, M. A.Botella, J. S.Rubio, F.García-Sánchez and V. Martínez. 2010. Systems involved in $\mathrm{K}+$ uptake from diluted solutions in pepper plants as revealed by the use of specific inhibitors. $J$. of plant physiology. 167(17):1494-1499.

Savvas, D., E.Stamati, I. L.Tsirogiannis, N.Mantzos, P. E.Barouchas, N.Katsoulas and C. Kittas. 2007. Interactions between salinity and irrigation frequency in greenhouse pepper grown in closed-cycle hydroponic systems. Agricultural Water Management.91(1-3):102111.

Sekhon. 2010. Water use efficiency under stress environments. In: Climate Change and Management of Cool Season Grain Legume Crops. Springer Netherlands, pp. 207-227

Shahbaz, M. and M. Ashraf. 2013. Improving salinity tolerance in cereals. Critical Reviews in Plant Sci. 32(4):237-249.

Sieprawska, A., A.Kornas, M. Filek. 2015. Involvement of selenium in protective mechanisms of plants under environmental stress conditions-review. Acta Biologica Cracoviensia. Series Botanica. 57(1).

Simojoki, A., T. Xue, K. Lukkari, A. Pennanen and $\mathrm{H}$. Hartikainen. 2003. Allocati of added selenium in lettuce and its impact on roots. Agric. and Food Sci. in Finland. 12: $155-164$.
Sivasankaramoorthy, S., T.Balasubramanian, P.Amuthavalli, and P.Sivaraman. 2011. The effect of salinity on organic components of Excoecaria agallocha L. J. Experim. Sci., 1(12):33-41.

Tan, K. H. and V. Nopamornbod. 2005. Effect of different levels of humic acids on nutrient content and growth of corn (Zea mays L.). J. Plant \& Soil. 51 (2):283-287

Wang, Z., X. Xie, J. Zhao, X. Liu, W. Feng, J. C.White and B. Xing. 2012. Xylem- and phloem-based transport of $\mathrm{CuO}$ nanoparticles in maize (Zea mays L.) Environ. Sci. Technol. 46:4434-4441DOI: 10.1021/es204212.

Xue, T., H. Hartikainen and V. Piironen. 2001. Antioxidative and growth promoting effect of selenium on senescing lettuce. Plant Soil. 237:55-61.

Yassen, A. A., M. A.Safia and M. Z.Sahar. 2011. Impact of nitrogen fertilizer and foliar spray of selenium on growth, yield and chemical constituents of potato plants. Australian J. Basic Applied Sci. 5(11):1296-1303.

Yildirim, E., M. Turan and I. Guvenc. 2008. Effect of foliar salicylic acid applications on growth, chlorophyll and mineral content of cucumber grown under salt stress. Biol. Planta. 593- 612.

Zhang, J. L. and H.Shi. 2013. Physiological and molecular mechanisms of plant salt tolerance. Photosynthesis research. 115(1): 1-22.

Zhou, Y., Z.Wen,, J.Zhang, X.Chen, J.Cui, , W.Xu and H. Y. Liu. 2017. Exogenous glutathione alleviates salt-induced oxidative stress in tomato seedlings by regulating glutathione metabolism, redox status, and the antioxidant system. Scientia Hort. 220:90-101.

\title{
الملخص العربي
}

\section{تأثير اضافه الجلوتاثيون والسلينيوم وحمض الهيوميك على تقليل الاجهاد الملحى وتحسين النمو لنبات الفلفل الحلو}

\author{
حسن احمد الخطيب، سعيد محمد جبر، احمد عبد الله عبد الفضيل العزومى \\ والمحصول لنبات الفلفل الحلو انخفضت بزيادة مستوى \\ الملوحة. بالنسبة لمعاملات الجلوتاثيون والسيلينيوم وحمض \\ الهيوميك، اظهرت النتائج إن استخدام السيلينيوم بمفرده في \\ الموسمين الأولين أو مع الجلوتاثيون في الموسم الثالث كان \\ له تأثيرات معنويه في زيادة نمو النبات والمحتوى الكيماوي \\ والمحصول تحت أعلى مستويات الملوحة المستخدمة. \\ اجريت ثلاث تجارب فى اصص بمزرعة خاصة

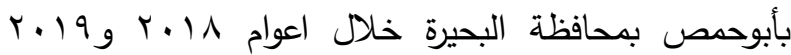 \\ و.r.r.r. لدراسة تأثير الجلوتاثيون والسيلينيوم وحمض \\ الهيوميك منفرده في الموسمين الأولين او فى ازواج في \\ الموسم الثالث. على تقليل الاجهاد الملحى على النمو \\ الخضري والتركيب الكيميائي والمحصول لصنف الفلفل الحلو \\ "مدريد". وقد أوضحت النتائج أن النمو والتركيب الكيميائي
}

